\title{
Lorca in English
}

Lorca in English examines the evolution of translations of Federico García Lorca into English as a case of rewriting and manipulation through politically and ideologically motivated translation. As new translations of Federico García Lorca continue to appear in the English-speaking world and his literary reputation continues to be rewritten through these successive re-translations, this book explores the reasons for this constant desire to rewrite Lorca since the time of his murder right into the 21st century. From his representation as the quintessential Spanish Republican martyr, to his adoption through translation by the Beat Generation, to his elevation to iconic status within the Queer Studies movement, this volume analyzes the reasons for this evolution and examines the current direction into which this canonical author is heading in the English-speaking world.

Andrew Samuel Walsh is a lecturer at Comillas Pontifical University Madrid and is the author of three books and numerous articles in the field of Translation Studies and Comparative Literature, including Jaime Gil de Biedma and the Anglo-American Tradition and Literary Retranslation in Context, and several publications on the history of Lorca in English translation. 


\section{Routledge Interdisciplinary Perspectives on Literature}

117 The Anthropocenic Turn

The Interplay between Disciplinary and Interdisciplinary

Responses to a New Age

Edited by Gabriele Dürbeck and Philip Hüpkes

118 Beards and Masculinity in American Literature Peter Ferry

119 Kashmiri Life Narratives

Human Rights, Pleasure and the Local Cosmopolitan Rakhshan Rizwan

120 Migrant and Tourist Encounters

The Ethics of Im/mobility in $21^{\text {st }}$ Century Dominican and Cuban Cultures

Andrea Morris

121 Painting Words

Aesthetics and the Relationship between Image and Text

Beatriz González-Moreno and Fernando González-Moreno

122 The Role of the Literary Canon in the Teaching of Literature Robert J. Aston

123 The New American West in Literature and the Arts

A Journey Across Boundaries

Edited by Amaia Ibarraran-Bigalondo

124 Lorca in English

A History of Manipulation through Translation

Andrew Samuel Walsh

For more information about this series, please visit: https://www.routledge.com 


\title{
Lorca in English \\ A History of Manipulation through Translation
}

\author{
Andrew Samuel Walsh
}

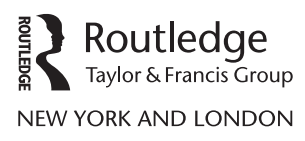


First published 2020

by Routledge

52 Vanderbilt Avenue, New York, NY 10017

and by Routledge

2 Park Square, Milton Park, Abingdon, Oxon, OX14 4RN

Routledge is an imprint of the Taylor \& Francis Group, an informa business

(C) 2021 Taylor \& Francis

The right of Andrew Samuel Walsh to be identified as author of this work has been asserted by him in accordance with sections 77 and 78 of the Copyright, Designs and Patents Act 1988.

All rights reserved. No part of this book may be reprinted or reproduced or utilised in any form or by any electronic, mechanical, or other means, now known or hereafter invented, including photocopying and recording, or in any information storage or retrieval system, without permission in writing from the publishers.

Trademark notice: Product or corporate names may be trademarks or registered trademarks, and are used only for identification and explanation without intent to infringe.

Library of Congress Cataloging-in-Publication Data

Names: Walsh, Andrew Samuel, author.

Title: Lorca in English : a history of manipulation through translation / Andrew Samuel Walsh.

Description: New York : Routledge, 2020. I

Series: Routledge interdisciplinary perspectives on literature I

Includes bibliographical references and index. I

Summary: "Lorca in English examines the evolution of translations of Federico García Lorca into English as a case of rewriting and manipulation through politically and ideologically motivated translation"- Provided by publisher. Identifiers: LCCN 2020013077 | ISBN 9780367262150

(hardback) I ISBN 9780429292040 (ebook)

Subjects: LCSH: García Lorca, Federico, 1898-1936-Criticism and interpretation. I García Lorca, Federico, 1898-1936Translations into English-History and criticism.

Classification: LCC PQ6613.A763 Z9186 2020 I

DDC 868/.6209-dc23

LC record available at https://lccn.loc.gov/2020013077

ISBN: 978-0-367-26215-0 (hbk)

ISBN: 978-0-429-29204-0 (ebk)

Typeset in Sabon

by codeMantra 


\section{Contents}

Introduction $\quad 1$

1 Lorca Cannot Be Englished? $\quad 12$

2 Early Translations and Reception 30

3 'The Martyrdom of an Entire People' 61

4 The Beat Generation's Adoption of Lorca 102

5 'Everybody Says I Love Lorca.' 120

6 'The Fairy Son of Whitman' 131

7 'The Mask Arrives on Wall Street' 148

8 'The King of Harlem Sings with the Crowd' 160

Conclusions: On Lorca's Afterlives through Translation

Bibliography 179

Bibliography of Lorca in English Translation $\quad 185$

Index 201 

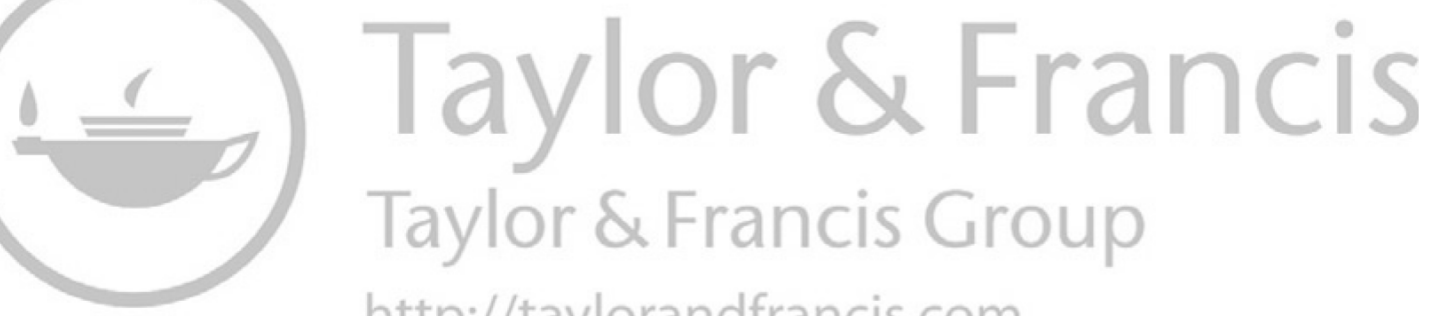
http://taylorandfrancis.com 


\section{Introduction}

¿Existió alguna vez Lorca, o será todo una creación poética que nos tiene sugestionados? ${ }^{1}$

(Basilio Martín Patino)

Since his murder in Granada by local Fascists at the outbreak of the Spanish Civil War, the works of Federico García Lorca (1898-1936) have been translated completely or partially into English on numerous occasions to a degree that in Spanish literature only admits comparison with Cervantes. ${ }^{2}$ The list of translators of his work is much too long to reproduce here but includes fellow poets as diverse and as distinguished as Stephen Spender, Langston Hughes, Roy Campbell, and Ted Hughes, and this list has grown exponentially and shows no signs of waning as Lorca continues to fascinate internationally. Nevertheless, what is generally supposed to be the quintessentially Spanish yet simultaneously protean nature of the work of Lorca, its constant and conscious oscillation between the traditional and the avant-garde, has given rise to some very mixed results in the abundant English translations of his poems and also in the plays which have been produced and performed since 1929 when the first version appeared. Specifically, the most popular elements of his rural dramas, the flamencoesque references and use of a heavily stylized world of Gypsies that characterize his most Andalusian poetry, have proved to be notoriously resistant to translation, which was initially and then traditionally attributed to his widely perceived exotic, racial otherness.

This book aims to provide a history of the reception of Lorca's work through English translation and the extent to which it may have been manipulated through this medium. It does not seek to provide yet another contribution to the interpretation of his work or attempt further exegesis of its relation to his life, of which there is a long and ongoing tradition. Nor does it seek to contribute to the multiple and seemingly infinite ideological and identity-based political readings of Lorca, nor add to the hermeneutical approach that has spawned so many pages since his death, but rather to examine how Lorca's translation into English has led 


\section{Introduction}

to a reception that has fluctuated enormously according to the ideological tendencies of the translators and the texts that they have chosen to render into English. The excesses of interpretation (what Susan Sontag famously referred to as 'the intellect's revenge upon art') have led some critics to assure their readers that Bodas de Sangre [Blood Wedding] ${ }^{3}$ is really a play about two men's mutual desire to penetrate each other, that Poeta en Nueva York [Poeta en Nueva York] is a disturbingly racist text based on white privilege, constructed from the perspective of cultural appropriation, or propose that Lorca's poetics belongs to the tradition of 'romantic hermeneutics' ${ }^{4}$ along with Jacques Derrida and Martin Heidegger among other similarly impressive critical and philosophical touchstones. Yet two pages later, the same critic also refers, rather contradictorily, to Lorca's 'radically modernist hermeneutics and poetics,' a clear example of how Lorca has become something of a tabula rasa on which to project seemingly any theoretical interpretations, no matter how far-fetched and essentially anachronistic these might appear to a less meta-theoretical reader of his work.

Although an endless procession of critics have sought to claim authority in their readings and interpretations of his work and establish their 'take' on Lorca as the 'right' one, the definitive, hegemonic reading, I believe that Lorca cannot be tied down to a single, frequently selfaggrandizing reading, which refers categorically to those who 'get Lorca wrong.' Nobody will ever be able to fully separate the myth and the texts, ${ }^{5}$ and the very history of Lorca's reception in the English-speaking world has taught us that there can never be any single, hegemonic 'take' on Lorca. Consequently, the pages that follow will seek to circumvent the potentially infinite disquisitions regarding the interpretation(s) of Lorca and the concomitant controversy as to who is 'right' and who is 'wrong' in terms of their hermeneutical struggle around the work and the figure of Lorca. Instead, this book will try to focus empirically on how his radically changing ideological and aesthetic reception in the English-speaking world has been constructed around the multiple and often profoundly dissonant translations and subsequent presentations of his work in English, which we will examine from a diachronic historical perspective to analyse just how diversely Lorca has been 'Englished.' In Apocryphal Lorca, his groundbreaking study of Lorca's resonance in the work of twentieth-century American poets, Jonathan Mayhew stated that 'my focus is on the translation of works that Lorca did not write' (2009, xiv). Mine is on exactly the opposite.

Nevertheless, any examination of the history of Lorca's reception through his Anglo-American translations must also implicitly address the question of why this work has resonated so strongly in the English-speaking world, and appraise the competing schools of domestication or foreignization of his work among his Anglo-American translators. ${ }^{6}$ Crucially, Lorca's work is read so much more closely in 
relation to his turbulent biography than any other contemporary writer, in both Spanish and English translation. Proving the perspicacity of Jorge Luis Borges's observation regarding the habitual approach to the great works of the literary canon, the initial distortion to his reception lies in the fact that most of Lorca's readers have somehow 'already read his work.' In this respect, Federico Bonaddio has also noted that 'the fact remains that it is difficult to come to his work in total ignorance of his biography, such has been our exposure, particularly over the last twenty years or so, to the personality we call Lorca' $(2007,14)$. Without descending to the lowest common denominator of critical reductionism, which suggests that his biography explains everything about the work, it is undeniable that the background to his life and the tragic nature of his death have exerted a potent and lasting influence upon the reception of his work in the English-speaking world and his new readers are conditioned by this before their first contact with his texts. One of the most outstanding and enduring examples of this is the endless recourse to the hoary old cliché of the duende, invoked by so many English-speaking poets and critics to explain the peculiar and supposedly 'racial' genius at the root of Lorca's creativity. Starting in his own lifetime with the quasi-gypsy, Orientalist poet who was the very embodiment of mythical Andalusia, Lorca has frequently been in danger of disappearing completely behind the all-pervading cultural cliché in which the myth has displaced the work itself. This myth has further been constructed around the angst-ridden avant-garde poet who was simultaneously alienated and fascinated by New York, the left-wing martyr of the Second Republic, the sacrificial lamb of Spanish Civil War, the enduring gay icon whose sexuality at least partly explains why he was murdered, and the emblematic author of the Transition from dictatorship to democracy in modern Spain. However, despite this enormous amount of para-literary baggage that generation after generation of readers have tended to bring to Lorca, the attendant risk of trivialization or distortion of his work, and the tendency to confuse this with his life, ${ }^{7}$ the continued interest in the translation and performance of his work in the English-speaking world has meant that 'Lorca's work has survived lorquismo itself,' to use the apposite phrase coined by his fellow granadino Luis García Montero in a Spanish state TV documentary made in 1998 to mark the centenary of the poet's birth.

According to Lawrence Venuti in The Scandals of Translation, 'Translation wields enormous power in constructing misrepresentations of foreign cultures' (1998, 67), and I believe that Lorca's work in its English renderings has suffered from an egregious example of misrepresentation through translation. Despite the persistent myth of the untutored, impenetrably Spanish genius, driven by the dark forces of the duende, as Jonathan Mayhew sagely notes, 'Lorca was in fact a cosmopolitan intellectual who came of age during the epoch of the historical avant-garde 


\section{Introduction}

in Europe' $(2009,10)$. Nevertheless, according to Ángel del Río, a friend who knew him well and was in close contact with him during his time in the United States, 'it can be safely affirmed that the poet knew little, at least directly, of modern American literature. Lorca had a remarkable impatience with any language other than Spanish. Practically all he read of foreign literature he read in translation' (1955, xxx). Despite his stubborn monolingualism in speech, ${ }^{8}$ Lorca was certainly no unschooled, intuitive genius from rural Andalusia. Even though he frequently and meretriciously claimed that he had read only two books in his life, on other occasions he boasted about reading two books a day. ${ }^{9}$ It must be admitted that Lorca was a compulsive and a creative liar who once claimed that Max Reinhardt, then the preeminent theatre director on Broadway and in Europe, was going to stage La Zapatera Prodigiosa [The Shoemaker's Prodigious Wife] in New York. ${ }^{10}$ Lorca certainly read widely and productively, both in his native Spanish and in translation, including the work of Shakespeare, Oscar Wilde, T.S. Eliot, and a long list of other Anglophone authors, and his theatrical craft was also far more cosmopolitan in terms of its inspiration and erudition than he is often credited with.

The underlying problem is that Lorca the writer has been devoured by Lorca the cultural cliché which has been so pervasive and persuasive among many of his English-speaking translators and readers, although it must be admitted that a parallel phenomenon means that there is also still a considerable obstacle to a balanced reception of his work in Spanish too. Indeed, this fatal tendency to resort to a handy assortment of passionate, Gypsy clichés is neither historically recent nor has it been the exclusive preserve of English-speaking translators, critics, and journalists. ${ }^{11}$ Thus, as early as 1934, during Lorca's triumphal theatrical tour of Argentina and Uruguay, the Montevideo daily newspaper $\mathrm{La}$ Mañana devoted its front cover of 6 February 1934 to the following headlines accompanied by a photo of a suitably swarthy, intense, and still youthful-looking Andalusian poet: 'Federico Garcia Lorca. Gitano auténtico y poeta de verdad. Toda su obra: alma y pasión arrastradas en torrente caliente de música y fulgurante de imágenes' [Federico Garcia Lorca. An authentic Gypsy and a true poet. All of his work: soul and passion dragged along in a hot stream of music and dazzling images.].

This rewriting and reinvention of Lorca through translation is ongoing, and it is worth asking whether or not Lorca's life and death have created more interest and more 'rivers of ink' (to borrow the traditional Spanish expression for copious amounts of writing) than his work itself. Those who have had and continue to have an agenda to create and promote gay, Andalusian, left-wing, or Catholic Lorca, to name just a few of the traditional agendas, are reluctant to relinquish this convenient ideological crutch, and so it remains extremely hard to shake off a simplistic, romantic, even kitsch reading of Lorca. This approach might best 
be described as the 'Loco for Lorca' approach, to borrow the title given to an October 2019 reading and celebration of his work in English and Irish at the Seamus Heaney HomePlace in Northern Ireland, which has its Spanish equivalent in the title of the Catalan flamenco singer Miguel Poveda's 2018 homage to Lorca, Enlorquecido, a pun which blends the poet's name with the same romantic idea of being enloquecido, or 'loco' for his work.

In order to more fully understand the nature of the process through which Lorca went from being considered an untranslatable, intensely ethnocentric author whose widely perceived 'otherness' was an insuperable barrier to translation into foreign literary cultures, to a celebrated, hypercanonical author whose work has been widely translated and successfully performed, I propose to undertake the analysis of this question in a chronological manner over the course of eight thematic chapters, each of which will focus on a different aspect of the evolution in this reception. The first chapter will provide some initial reflections on translation, translatability, and canonicity, and address the fundamental question of whether or not Lorca is essentially translatable or, as many have believed, is instead such a culturally remote and exotic author that his work will always present an excessive degree of 'otherness' and resistance to translation. The second chapter will examine Lorca's presence in the English language before his murder in 1936, and therefore, focuses entirely on what we can consider to be the entirely non-political and pre-mythical version of his work in translation. It seeks to examine what evidence we can find of Lorca in English before his many afterlives through translation began to appear. Although this is not specifically reflected in the UNESCO bibliographical archive on translations, to which we will refer more extensively in due course, Lorca's work was translated into English as early as August 1929, in a special edition of the Hispanic journal Alhambra during Lorca's New York sojourn from June 1929 to May 1930. Moreover, during this same visit to the United States, Lorca had also collaborated closely with his friend Philip Cumming's translations of his Canciones [Songs], although this text would not be published until 1976. Lorca was, however, involved in the subsequent translation and production of his play Bodas de Sangre, which was translated into English by José Weissberger with the wayward and utterly confusing title of Bitter Oleander and performed to decidedly mixed reviews in 1935 at the Lyceum Theatre in New York to an audience who knew nothing of Federico García Lorca and were utterly bemused and even unintentionally amused by this version of his play, as we shall see in more detail in this chapter. This first phase of Lorca in English during his own lifetime, the early translations, and the initial projects of English versions of his work that were proposed during his time in New York is one essentially characterized by the perceived 'otherness' of his work and its identification as profoundly, perhaps impossibly Spanish. 


\section{Introduction}

Chapter 3 looks at the early process of Lorca's literary and political martyrdom in the United States and the UK. Despite the aforementioned translations made during his lifetime, and his own personal collaboration in some of these versions, it was not until after his murder that the veritable deluge of politically oriented Lorca translations in English began to appear. Thus, in London in 1937 Heinemann published Lament for the Death of a Bullfighter and Other Poems, translated and prefaced by the Communist activist A.L. Lloyd, while other versions of his work translated by Republican sympathizers such as Stephen Spender and Rolfe Humphries would appear before the end of the decade. Nevertheless, it must be remembered that Lorca was being claimed exclusively in English translation not only by the Left but also by the Falange and the Catholic Right in Spanish, whose 'official' writers had already begun their attempt to disassociate themselves and Franco's regime from Lorca's murder. Thus, during the 1950s right-wing (and clandestinely homosexual) Spanish poets such as Leopoldo María Panero and Luis Rosales (who was so closely and tragically associated with Lorca's death) ${ }^{12}$ began to write homages that timidly tried to defend Lorca and even his sexuality. ${ }^{13}$ In a parallel vein of Falangist appropriation, in 1952, the South African poet and Franco hagiographer Roy Campbell (a man who in 1939 would publish a pro-Fascist panegyric entitled Flowering Rifle which referred to the 'the victorious bread-giving regime of Franco') published a volume entitled Lorca, an Appreciation of His Poetry, a concerted attempt to wrest control of Lorca's reception away from the Left, who he believed had misrepresented the Andalusian poet's work through translations which had turned him into a martyr of the Spanish Republic.

Chapter 4 studies the process through which during the 1950s and onwards Lorca became a relatively popular and comparatively depoliticized figure among American readers and writers of poetry. Specifically, 1955 saw a significant shift in terms of Lorca's reception through translation with the simultaneous publication of the New Directions bilingual anthology of his poetry entitled The Selected Poems of Federico Garcia Lorca, and Ben Belitt's translation of Poeta en Nueva York [Poet in New York]. On the back cover of The Selected Poems, the editors of this first collection of English language translations of Lorca's poetry his brother Francisco García Lorca and the poet Donald M. Allen could categorically state, 'No other poet of the twentieth century has attracted more English-speaking translators than Lorca, whose clarity and lyricism particularly recommend themselves to poets working in the Anglo-American vernacular.'

Chapter 5 examines how the abundance of translated versions and performances of Lorca's work during the Transition to democracy in Spain notably reinforced his reputation as a symbol of the new Spain, and how English-speaking translators unanimously recuperated the Civil 
War martyr. After almost forty years of Franco's dictatorship, Lorca was celebrated worldwide as the emblematic author of a newly open and liberal Spain that was throwing off the shackles of the past, and the renewed interest in his work was reflected in an abundance of new English versions of his poems and plays. Now his quintessentially Spanish otherness seemed positively attractive and just as he no longer appeared to have any detractors on the Spanish Right, international audiences were presented with a universally revered and increasingly canonical figure.

Lorca's gradual adoption as a key figure in the gay canon is the subject of Chapter 6. This process had already been undertaken to some extent in the 1950 s by poets such as Allen Ginsberg, Jack Spicer, and Frank O'Hara, among many others, whose lorquismo we will explore in this chapter. However, this process far transcended the US Beats' surrealist reading of Lorca and has remained very much an essential part of his reception through English translation to this day, just as the Anglophone perception of Lorca as quintessential politicized/Civil War martyr has never entirely left us. Chapter 7 is entirely devoted to the prolific and complex relation between Lorca's work and the city of New York. As is well known, the very title of Poeta en Nueva York was intended to sound ironic, almost like an absurd oxymoron, as Lorca's conception of what a poet and poetry meant could not have been any further removed from the teeming, chaotic metropolis that provided the inspiration for and the backdrop to these poems. It is thus profoundly ironic that his invective against the dehumanization he encountered in New York has reaped such a rich harvest in American poetry and other art forms in that nation's culture. Specifically, Lorca has become intensely identified with the city of New York through the abundant retranslation of the poems from what is now generally considered to be a Modernist classic. Indeed, it is possible to speak of a clearly distinguishable historic dichotomy in terms of translational preferences between the Andalusian, supposedly traditional Lorca, and the surrealist transgressor of the New York poems. The association with New York became increasingly strong in the light of the tragic events of 11 September 2001, after which Lorca's poems about the devastation that would be wreaked on the Wall Street of the period immediately before and after the 1929 Stock Market Crash were chillingly recalled in the days that followed the terrorist attacks on the World Trade Center. As we will see in this chapter, such was the extent of the re-reading of these poems in translation after those tragic events in Manhattan, that two New York poets and translators were sufficiently moved to produce a new rendering of the text in the light of some of the quite startling premonitions found in some of Lorca's New York poems. Lorca's close association with the city of New York has continued to be evinced by the many texts and literary events that have brought the two names together. Indeed, along with his hometown of Granada, the city of New York is perhaps the place most readily 


\section{Introduction}

associated with Lorca, certainly among English-speaking readers of his work. However, in very recent times Lorca's New York poetry has begun to be read in a rather troubling vein amid incipient accusations of cultural appropriation and even a certain paternalistic, romantic racism, which is the topic of the last chapter of the book. Thus, Chapter 8 will examine Lorca's authorial status in the English-speaking world in the twenty-first century and consider where this reception is heading in the light of current debates around political correctness and cultural appropriation. The growing presence of feminist and LGBT readings of García Lorca (who wrote some of the most daring homoerotic verses in Spanish literature) in the English-speaking literary world undoubtedly continues to condition the reception of his work.

There are a vast and ever-growing number of translations of Lorca's work into English, and it would be materially impossible to analyse all of them in any great detail within the confines of a single book. Therefore, I have decided to provide an overarching view of the main historical tendencies, starting with the handful of early versions that appeared during his own lifetime and reaching as far as the abundant present-day versions that continue to appear well into the twenty-first century. Indeed, new versions of Lorca in English have continued to be published as I have been writing this book and, whether it be Andalusian, Spanish, American, gay, left-wing, or perhaps even universal Lorca, there would appear to be an enduring appetite in the English-speaking world for translations of a poet and dramatist whose work was at first thought to be so irretrievably exotic, culturally remote, and essentially just 'too Spanish' to make any sense to English-speaking readers and audiences. Ironically enough, this supposedly exotic and culturally alien work has proven to be the most widely translated of all Spanish poets and dramatists in the twentieth century and beyond and also one of the most universally celebrated poets in translation in world literature.

The aim of this book, therefore, is to provide a broad historical overview and selective analysis of a very long history of Lorca's translation into English and, specifically, the notable tendency to manipulate his work through this medium of cultural interaction. As stated previously, it is evidently impossible to analyse all of the translations in depth, and therefore, I have paid much greater attention to what I consider to be some of the key translators for what I will try to argue are the right and the wrong reasons, such as Langston Hughes, Ben Belitt, Roy Campbell, or Jack Spicer. I will also try to demonstrate my initial hypothesis that Lorca presents a paradigmatic case of manipulation, misrepresentation, and even misappropriation through translation. I will focus on identifying the main tendencies and, in certain cases, provide a more in-depth analysis, but, as stated previously, a complete comparative and contrastive analysis of all English Lorca translations would be simply unfeasible in one book. 
Inevitably, this book cannot be exhaustive as there are far too many translations of Lorca to consider, and this tendency to hypertranslation is certain to continue, as his work is now officially out of copyright in Spanish since the beginning of 2017, and indeed since then there has been a renewed proliferation of new versions. In fact, the whole question of copyright concerning Lorca's work in Spanish and in translation is a thorny issue, although in theory his work came out of copyright in Spain at the beginning of 2017 along with the work of authors such as Unamuno, Valle-Inclán, Muñoz Seca and Ramiro de Maeztu (the latter two, like Lorca, were killed at the beginning of the Spanish Civil War). ${ }^{14}$ Many of these new translations of Lorca follow the newly affordable trend for self-publishing and exclusively online availability. Furthermore, over the decades since his murder, there have also been numerous English versions of his drama which have not been published and which have been performed by amateur or student theatre companies. As we have stated previously, there are simply too many translations to analyse them all, although the bibliography of Lorca in English translation which appears at the end of this book attempts to provide the most complete and up-to-date picture of his presence in the English language as it is possible to obtain, given his enduring popularity in translation and the aforementioned end of copyright restrictions in 2016 which is already pointing to a very recent spike in new versions. The history of Lorca in English, therefore, is sure to continue and the closing section of Conclusions to this book will attempt to hazard an educated guess as to what direction Lorca's translational afterlives in English will take in the near future. What is beyond all doubt is that since his death in 1936 and until the time of writing this book, his work has been subject to constant, ideologically motivated retranslations which, in my view, have frequently represented a form of manipulation, and it is this history of manipulation through translation that this book will now attempt to address.

\section{Acknowledgements}

For their encouragement and generous assistance with this project, special thanks are due to the Professors Andrew A. Anderson, Federico Bonaddio, Christopher Maurer, and Evelyn Scaramella, without whose academic generosity and reciprocity this study would not have been possible. Laura García Lorca's kind assistance and encouragement were important too in making this book seem a reality from the early stages of its conception. I would also like to acknowledge my gratitude to my colleagues from Comillas Pontifical University in Madrid, Professor Susanne Cadera, and Professor Dolores Rodríguez Melchor, for their constant support for my research and my numerous talks on this subject in Spain and much further afield. The staff at the British Library 


\section{Introduction}

in London, the Biblioteca Nacional in Madrid, and Rocío Líñan at the Centro Federico García Lorca in Granada have also provided invaluable assistance for my work, as well as the undeniable privilege of working in such beautiful research spaces.

And finally, I would like to dedicate this Anglo-Andalusian study to my English and Spanish families, and thank them for their steadfast support in helping this book see the light of day, and very especially to my own granadinos, my children Alba and Sammy, for their patience with their father's all-consuming obsession with proving that Lorca can indeed be Englished, and in the hope that the homophobia and the intolerance that contributed to the murder of Federico play no part in the lives of their generation of Spaniards.

\section{Notes}

1 Did Lorca ever really exist, or is he just a poetic creation that has hypnotized us all?

2 Although Lorca is often casually cited by Hispanists as Spain's most translated author, he is actually in third place in terms of the total number of translations of his work. According to an article published in El Pais on 11 May 2016, after Spain's most translated author, Miguel de Cervantes, the second position on the list was still occupied by a certain José María Parramón Vilasaló, a specialist who wrote manuals for amateur painters. According to the Index Translation of UNESCO which, as we know, must be taken with a sizeable pinch of salt, the current top ten of Spanish language authors in translation into all languages is as follows: (1) Gabriel García Márquez; (2) Isabel Allende; (3) Mario Vargas Llosa; (4) Miguel de Cervantes; (5) Jorge Luis Borges; (6) José María Parramón Vilasaló; (7) Federico García Lorca; (8) Pablo Neruda; (9) Julio Cortázar; (10) Manuel Vázquez Montalbán. Accessed 12 October 2019. https://verne.elpais.com/ verne/2016/05/05/articulo/1462441545_771155.html

3 From now on, the original Spanish titles of each work by Lorca will be used and an English translation of this title will be given only the first time the title appears.

4 Jonathan Mayhew has recently spoken of 'Lorca's place within the tradition of romantic hermeneutics to which he belongs' $(2018,2)$.

5 According to Paul Julian Smith,

García Lorca is perhaps the most extreme case of proprietorial authorship in Spanish literature: it seems impossible to approach his texts without acknowledging his person, and it is almost an article of faith amongst critics that in Lorca literature and life are one.

$(1998,107)$

6 In his essay 'Pragmatic Comments on Translating Lorca,' Leo Hickey notes that

It is important to acknowledge that Lorca uses language which is very often marked, non-standard or unexpected, stimulating peculiar effects relating to a world that is not quite any real world. Therefore, it would seem that, to de-contextualise a text, to translate it into familiar, Standard English, or to set the scene in any world that English readers would recognise as their own might preclude such an effect. 
7 This author was once solemnly assured by a foreign exchange student that Lorca was 'a gypsy flamenco dancer who lived in a cave in the Sacromonte in Granada.'

8 According to Christopher Maurer, Lorca was an 'empecinado poeta monolingue' [a stubbornly monolingual poet] $(1992,16)$.

9 See Stainton $(1998,121)$.

10 See Federico García Lorca $(1986,408)$, Vol. III.

11 In this sense, the title of a 1998 English language centenary celebration of his work (Lorca: Fire, Blood and the Alphabet) is eloquent. It seems that everything surrounding Lorca has to be passionate, excessive, and even slightly atavistic.

12 There is an abundant literature on the role of the Rosales family in Lorca's last few days before his execution, including a book entitled El Silencio de los Rosales [The Silence of the Rosales Family], published in 2002 by Luis Rosales's nephew, Gerardo. For the most detailed study of this question, see Federico García Lorca. Vida, Pasion y Muerte. [Federico García Lorca. Life, Passion and Death] by Ian Gibson (2016) and Lorca. El Último Paseo [Lorca. The Last Walk] by Gabriel Pozo Felguera (2009).

13 'According to María M. Delgado,

In Spain, the right of centre poets, Leopoldo Panero and Luis Rosales, both, like Lorca, homosexual, rendered homages that could be read by a readership who knew the discrete borders around which the public utterance of sexuality could take place.

$(2008,177)$

14 Accessed 12 November 2019. https:/elpais.com/cultura/2016/12/30/ actualidad/1483092260_837815.html

1 It should not be forgotten that Lorca was in fact sued over this composition by a member of the Civil Guard and was extremely worried about its repercussions, justifiably so as it has often been cited as one of the many possible reasons for his murder in Granada in 1936.

2 This was the figure when last checked on 22 February 2020.

3 This anthology contained the first English translations of the fragment of the sonnet ' $\mathrm{O}$ Oh cama del hotel! Oh dulce cama! [Oh hotel bed, oh this sweet bed] and 'Aquel rubio de Albacete' [That blond from Albacete].

4 'It is precisely because Lorca has roots in his native soil that he can teach us what we need in spite of having no 'message' and animate other European literatures and languages, in spite of the fact that he was ignorant of them $(1952,9)$.

5 See Rivas Cherif (1957).

6 In Palabra de Lorca, 580.

7 Gibson $(2016,486)$.

8 Adams also provided some more conflicting opinions regarding the breadth and cosmopolitanism of Lorca's reading. On the one hand, Jose Fernández Montesinos, the brother of Lorca's murdered brother-in-law Manuel, and a professor at Berkeley until the early 1970s, stated that 'no one among contemporary poets read less,' whereas Ángel del Río took the 'middle ground' and ventured his opinion that Lorca also read translations of the work of Victor Hugo, who was apparently 'his father's favourite author,' along with Ibsen and Shakespeare, 'whose entire work he read very young and continued to read all his life' (1977, 15-169). 
9 Maurer and Anderson $(2013,186)$.

10 A notable example can be found in 'New York (Oficina y denuncia)' [New York: Office and Denunciation], in which Lorca's poetic voice ‘¿Qué voy a hacer, ordenar los paisajes?' [What shall I do? Set the landscapes in order?] clearly echoes Eliot's original and unequivocally biblical exhortation from the final stanza of The Waste Land, 'Shall I at least set my lands in order?' which in itself is an echo of Jehovah's command to Hezekiah: 'put your land in order as you are going to die.'

11 I was sad looking at the crops/ It was a clear afternoon./ Sleeping between the pages of a thick tome/ Shakespeare kept me company.

12 'Another part of Lorca's sexual ideology is that homosexuals, who do not procreate, are the cultural creators.' In Eisenberg (2002, no page number).

13 Darío had written of Whitman as a 'gran viejo, / bello como un patriarca' [a great old man, beautiful like a patriarch], which Lorca in turn would reflect as 'viejo hermoso Walt Whitman' [beautiful old Walt Whitman].

14 See Gibson $(2010,294)$.

15 Alvaro Armando Vasseur was the translator of the first Spanish version of the work of Whitman and is thus considered largely responsible for the profound influence of Whitman on Spanish-speaking poets. It should be noted that the anthology translated by Vasseur and read by Lorca did not include the specifically homoerotic poems such as 'Native Moments' ('I share the midnight orgies of young men'), and, according to Ian Gibson, his translations of Whitman also tended to minimize gay references and thus make the male subject of the poems less obvious $(2010,296)$.

16 See Gibson (2010, 294-296).

17 See Eutimio Martín (1986, 91) and Gibson (2010, 294).

18 The translation was published in Buenos Aires in 1941 with the title Canto a mí mismo, a prologue by León Felipe himself and, curiously enough in the light of Lorca's Whitmanian evolution, an epilogue by Guillermo de Torre.

19 Tierra Baldía. Translation and prologue by Ángel Flores. 1930. Barcelona: Editorial Cervantes. In that same year, Flores complained personally to T.S. Eliot that another Spanish translation had appeared in Mexico, a fact which he felt contravened the promise of the exclusivity and authorized nature of his own translation.

20 For a detailed study of the intertextual relationship between Poet in New York and The Waste Land, see Young (1992). Young even states that such is the influence of Flores's translation on Lorca's germination of his New York poems, The Waste Land can even be considered to be as an 'intertext' of Poeta en Nueva York $(1992,177)$.

21 No one can imagine just what a New York crowd is like, except perhaps Walt Whitman, who searched it for solitudes, and T.S. Eliot, who squeezes the crowd like a lemon in his poem, extracting wounds, poets, wet hats, and river shades. Translation by Christopher Maurer.

22 Translated by José Robles, a close personal friend of Dos Passos and professor at Johns Hopkins University, who subsequently went missing in mysterious circumstances during the Spanish Civil War. For a complete investigation of this politically motivated disappearance and/or physical elimination of Robles, see Ignacio Martinez Pisón's (2006) novel Enterrar a los muertos [Burying the Dead]. 
23 León Felipe told his biographer Luis Rius that 'Él (Lorca) no quería estar dentro del grupo de maricas [...] era de una gran simpatía, lo quería todo el mundo; hombres, mujeres, niños, y él se sentía querido por todos, y debía de tener la tragedia de que un hombre tan afectuoso como él, y a quién le querían todos, no poder expresar de una manera [...] de esto sí quisiera, sí habría que hablar con cuidado' [He (Lorca) didn't want to be in the group of faggots [...] he was very friendly, everybody loved him; men, women, children, and he felt loved by everybody, and he must have felt the tragedy of a man as affectionate as he was, and who everybody loved, who couldn't somehow express [...] but I would like to and I have to be careful what I say about this]. In Gibson $(2016,412)$.

24 In 1962, José Luis Cano published the first biography of Lorca with the authorization and assistance of the family (see Adams, 1977, 19, 25).

25 Francisco García Lorca's' 'graphophobia' was confirmed by his daughter Laura in an interview with Christopher Maurer $(2018,328)$.

26 Laura García Lorca, the poet's niece and the daughter of Francisco García Lorca, personally confirmed this story to me in an interview at the Residencia de Estudiantes in Madrid on 7 March 2018 and further stated that the German translations 'sounded like Corín Tellado,' in reference to a well-known and prolific author of romantic Latin-American 'telenovelas' or soap-operas.

27 Accessed 12 November 2019. https://elpais.com/diario/1998/05/20/cultura/ 895615204_850215.html.

28 For a complete account of the events leading to the refusal to authorize what was by then the first English translation of Lorca's Complete Works, see Eisenberg (1987).

29 Obras Completas $(1986,565)$.

30 I understand all poetics; I could talk about them if I didn't change my mind every five minutes. I don't know. Maybe some day I will like bad poetry very much, the way I like (we like) bad music with a passion. I will burn down the Parthenon at night, to start to raise it again the next morning and never ever finish it.

31 What I want to highlight are his limitless nuances. Sometimes these nuances appear as different layers of meaning, and form substrata of different tones. These substrata, which run right through Lorca's work, are so deeply rooted that they become an integral part of his style.

32 Although everything related to meaning and metre is always problematic in a translation, it is this third 'bolita' [little ball], the substrata of meaning, which makes it impossible to be truly satisfied with the final result of any translation of García Lorca.

33 Maybe what I'm trying to tell you all with these circumlocutions is that nobody translates Lorca well. Even after translating eight of his works, I must admit that I only ever have two feelings when I finish one of these translations: a feelings of displeasure and another one of complete frustration; and these are feelings that I never have with the translations of other poets. Summing up: translating García Lorca is doomed to failure.

34 Greg Simon, one of the 1988 translators of Poeta en Nueva York, highlighted Lorca's repeated and frequently enigmatic use of words such as hueco and norma, and confessed to the enormous frustration that their translation had caused him: 
un traductor pronto descubre que todos los poetas dependen de palabras claves, a las que con frecuencia parecen ser adictos. En el lenguaje de un gran poeta, García Lorca, por ejemplo, hay palabras repetidas que están dotadas de la intensidad y el poder de un conjuro, y, en fuerte contraste de unas con otras, forman el esqueleto básico sobre el que Lorca cuelga sus ideas y emociones.

[a translator soon discovers that all poets depend on key words, to which they often seem to be addicted. In the language of a great poet, García Lorca, for example, there are words repeated that are imbued with an intensity and the power of a spell, and they are each in strong contrast with each other, forming the basic skeleton upon which Lorca hangs his ideas and feelings]

35 The translation theorist André Lefevere referred to ideology as 'the conceptual grid that consists of opinions and attitudes deemed acceptable in a certain society at a certain time, through which readers and translators approach text' in Hermans (2004, 127).

1 'I think that the poetry I'm writing in New York with graphics, words and drawings is something incredibly intense, so intense that they won't understand it and it will definitely provoke some arguments and scandal. But I'm sure that it's my best poetry and, of course, my intelligent American friends are looking for a poet to translate it, although I think that's going to be very difficult' (García Lorca, 1997, 677).

2 'I understood that they had murdered me/They searched the cafés and the cemeteries and the churches, they opened coffers and closets/ they destroyed three skeletons to tear out their gold teeth. /But they never found me/ No. They never found me.'

3 'The evening ended after 4a.m., with the poet and myself, arm in arm, helping one another down the steep streets of the Albaicín to the main Street, and the bottom of the Alhambra Hill.' '¡Noche, qué noche nochera!' (Trend, 1956, 4)

4 Trend (1926, 155-161).

5 'Madrid Chronicle' in the Criterion 4(2), April 1926, 357.

6 For a complete analysis of Trend and Marichalar's dissemination of Spanish culture through The Criterion, see Garbisu (2017).

7 The book was also very favourably reviewed by E. Allison Peers in the Bulletin of Hispanic Studies in the same year.

8 See Callahan $(1994,160)$.

9 According to Maurer and Anderson (2013, 240), Mildred Adams was actually the niece of Ray and Gertrude Brown, and she lived with them in New York, a fact which she curiously failed to mention in this description.

10 Maurer and Anderson $(2013,13)$.

11 See Maurer and Anderson $(2013,202)$ for more information about Nella Larsen's friendship with Lorca.

12 Isabel Soto quotes Richard Barksdale's biography of Langston Hughes, in which Barksdale refers to Lorca as 'a friend and fellow poet' of Hughes and also provides a quote from the Harlem Renaissance artist Romare Bearden which unequivocally states that the two poets were friends:

Lorca was studying at Columbia, and he was very friendly with Langston Hughes. I met him with Langston because Harlem was so small that when you gave a party everybody knew it, and Lorca, Federico García Lorca, was a friend of Langston's and Langston squired him around Harlem. 
13 Maurer and Anderson (2013, 33).

14 According to Brickell, Lorca's father 'was a small farmer, who like many Andalusians, had a touch of gypsy blood, while his mother was a descendant of one of the ancient Moorish families which have survived the years in the neighborhood' (1940, 206).

15 Accessed 17 November 2019. www.vqronline.org/essay/spanish-poet-newyork

16 For Lorca, 'English' simply meant 'English-speaking.' Thus, the following reference to breakfast with an 'English bank manager' needs to be taken cum grano salis, when he describes him as a 'persona encantadora con un fondo frío y felino de vieja raza inglesa' [a charming man with a depth of feline coldness and ancient English reserve] (Maurer and Anderson, 2013, 41).

17 'Around that time I was running a literary journal that was called Alhambra. It was a luxury, bilingual journal. The editor of the art section was Gabriel García Maroto. The journal was sponsored by a gentleman who turned out to be a conman: he didn't pay anybody. This man had wanted to recreate the atmosphere of the Alhambra on the eleventh floor of a building on the corner of 42nd Street and the Fifth Avenue: he imported mosaics from Spain and had a fountain built. He wanted to create a kind of Athenaeum: there were literary debates and a Spanish atmosphere.' In Herrero-Senés $(2019,211)$.

18 Maurer and Anderson (2013, 245).

19 According to Allen Ginsberg: 'He (Lorca) was hanging around Columbia University. His friend was the father of Juan de Onís who is now the Latin American reporter for the New York Times. De Onís were an elegant Spanish family, who ran away from the Spanish Civil War, were exiled (or were radicals, so they couldn't stay around, I forgot what the story was). And they were bilingual. And they were(he was) teaching at the head of the Spanish Department at Columbia [...] Several great poets came to New York during the (19)30s, at that time (Vladimir). Mayakovsky visited New York and wrote about the Brooklyn Bridge. And Lorca came to New York, but nobody knew him. Nobody knew who he was. Nobody knew who Lorca was except some of the Spanish community.' Accessed 23 November 2019. https://allenginsberg.org/2014/01/expansive-poetics-20-lorca-1/

20 The short-lived journal Alhambra also published English translations of works by Concha Espina, Gabriel Miró, Eduardo Zamacois, Valle-Inclán, Mariano Azuela, and José Moreno Villa.

21 See Herrero-Senés (2019).

22 Mildred Adams notes rather censoriously and with no little prudishness that

the friend who took Federico to Brooklyn to meet the American (Hart Crane) described it with some hesitation. Crane, whose homosexual tendencies were hardly secret, was at the time surrounded with young sailors. Illegal beer ran freely. All of them were drunk. It was not an ideal moment for an American poet and a Spanish poet to forge a friendship. There was even doubt that the American had comprehended who the Spaniard was.

(Adams, 1977, 122)

Despite Adams's reservations about this encounter, afterwards Lorca wrote his great poem 'Ciudad sin sueño. Nocturno del Brooklyn Bridge' [City without Sleep, Nocturne of Brooklyn Bridge]. 
23 See Maurer and Anderson (2013, 178).

24 'Of course, the poet of the "Romancero Gitano" neither writes nor speaks any other language but Andalusian Spanish.' In Alhambra, 1, $\mathrm{N}^{\circ} 3,24$.

25 Accessed 12 January 2019. www.proceso.com.mx/157474/angelflorestraductor-de-lorca-ellot-neruda-puente-entre-dos-lenguas.

26 According to Dionisio Cañas, who spoke to Cummings extensively about his relationship with Lorca and the time that the two of them spent together, they also slept together on the train in Cummings's compartment, much to the shock of Fernando de los Ríos and his niece who were Lorca's official travelling companions.

27 It seems more likely that they did not approve of what they presumably suspected was a homosexual relationship between the two friends, and, as late as 1955, Ángel del Río still insisted that they had fruitlessly tried to contact this American poet friend of Lorca but had been unable to establish his identity. Lorca's sister Isabel also denied that Cummings had visited Lorca in Granada in 1928, confirming the tendency of friends and family to obfuscate or simply deny any traces of homosexual friendships in Lorca's life. Most of Cummings's letters to Lorca and the corresponding replies would appear to have gone missing, as has occurred in so many other cases. For a complete analysis of the problems aroused by Lorca's friendship with Cummings, see Cañas (1989). Lorca's relationship with Rafael Martínez Nadal and the hostility it aroused among some of his family members would seem to be another paradigmatic case of this not so latent homophobia regarding the immediate family's control of the narrative of Lorca's life and work, also exemplified in the case of Eduardo Blanco-Amor's visit to the Lorca family home in Granada in 1934.

28 See Gibson (2016, 637).

29 For a much more detailed archive on Lorca's Vermont experience, see the extraordinarily detailed and lovingly updated blog 'Lorca in Vermont,' which is run by Patricia A. Billingsley. Accessed 12 January 2019. www.lorcainvermont. com

30 According to Cummings, Lorca entrusted him with a package full of manuscripts and instructed him to destroy them in X years if anything happened to him. Cummings confessed to having looked at the papers which contained the names of those people that Lorca felt were out to destroy him and eventually complied with his friend's wishes and burnt the papers. Note Gibson. In the end, Cummings gave different versions to different researchers such as Cañas, Gibson, and Adams, the latter of whom was entirely and unquestioningly on his side of events. Cummings also wrote to Angel del Río and told him another version about these papers.

31 No page number is given for this revised online version of the article.

32 During the 1950s, Cummings worked as a public speaker and analyst for the W. Colston Leigh Agency in New York, Washington, and San Francisco. Such was his success at this activity that he was repeatedly listed as the agency's most requested speaker on international affairs.

33 See the aforementioned 'Lorca in Vermont' website.

34 'Cummings' Spanish was fluent, and his love of both music and poetry very real' (Adams, 1977, 99).

35 See Cañas $(1989,29)$.

36 Eisenberg recognizes in his Introduction that 'this information comes from Cummings. I have been unable to find that this translation had been published at the time' $(1976,13)$. 
37 Eisenberg $(1976,13)$ even hints at some of the scarce information on Lorca translations into Norwegian and Portuguese in the 1930s, although no references are given.

38 In a letter to their common friend from the Residencia, Pepín Bello, Buñuel offered the following opinion of Lorca's Romancero Gitano: 'su libro me parece, y parece a las personas que han salido un poco de Sevilla, muy malo' [His book seems to me, and to everybody who has ever left Seville a little, a very bad one].

39 For the version given by Dionisio Cañas, see https:/elpais.com/diario/1985/ 12/22/cultura/504054008_850215.html.

40 The anthology also includes the following translations from twentiethcentury Spanish poets: 'The Dead Angels,' 'Punishments' and 'The False Angel' by Raphael Alberti (sic); 'Going Out,' 'The Shadows,' and 'Sea Fronts' by Jorge Guillén; 'The Dazzling Whiteness of my First Love,' 'Remorse,' and 'Dream Nocturne' by Juan Ramón Jiménez; 'The Martyrdom of St Olalla' by Federico García Lorca; 'At the Burial of a Friend,' 'The Street in Shadow,' 'Childish Dream,' and 'The Loved House' by Antonio Machado.

41 Let them put a cross of bitter oleanders on your breast.

42 'You can't say that it was a complete failure with the audience. The reviews said lots of stupid things. For example, that it was impossible for rural people to speak that way and other things like that. The critic of The [New York] Times was the only one who spoke clearly, since he started by confessing that he had understood nothing at all, and then added that a play like that could never be to the taste of an American, that it could never penetrate their civilization.'

43 'How he got around New York, with no English, and little sense of the geography of the city, was a continual surprise. He claimed to be able to say "Tim-es Es-quare" in four syllables, but nothing else. One day a friend appeared at a Columbia student restaurant and asked Federico in Spanish. "What are you eating"?. "I always have ham and eggs" was the answer "because I don't know how to ask for anything else” '(Adams, 1977, 119).

$44 \mathrm{I}$ can find no record of any other performance of a Lorca play translated into English and performed during his lifetime.

45 A work now widely attributed to his wife, Maria Lejárraga.

46 John Mason Brown in the New York Evening Post, 12 February 1935.

47 Bernard Sobel in the Daily Mirror 18 February 1935.

48 'The evidence of Hughes's translations points to a far more sophisticated and empathetic understanding of García Lorca's project, one that I argue, focuses on the male body as lost object' $(1998,45)$.

1 https://archive.nytimes.com/www.nytimes.com/books/99/09/12/specials/ lorca-theater.html. Accessed 13 November 2019.

2 This was not the case for Barea who never met Lorca personally ('I did not belong to his set, but belonged to his public, the people, and it is the people's Lorca whom I know' (1944, 12).

3 Hughes's annotated copy of this edition is now kept among his papers in the Beinecke Rare Book and Manuscript Collection at Yale University that located Hughes's translation of Bodas de Sangre thanks to a 'hunch' on the part of George Bass, who was a professor at Brown University and at the executor of the Langston Hughes estate and recalled that 'Langston might have translated that.' With Bass's help, she managed to track down the manuscript among the Hughes papers at the Beinecke Library at Yale University. She then began a process of researching and editing the manuscript with Bass until his death in 1990 (see Bensussen, 1994, x-xi). 
4 Covarrubias had also illustrated the covers of many key Harlem Renaissance texts such as Hughes's The Weary Blues.

5 Hughes did not translate the three 'historical ballads' that appear at the end of the original text: 'El Martirio de Santa Olalla,' 'Burla de Don Pedro a caballo,' and 'Thamar y Amnón.'

6 For a detailed study of Langston Hughes's work as a translator, see Kutzinski (2012).

7 Isabel Soto quotes Richard Barksdale's biography of Langston Hughes in which Barksdale refers to Lorca as 'a friend and fellow poet' of Hughes and also provides a quote from the Harlem Renaissance artist Romare Bearden which unequivocally states that the two poets were friends:

Lorca was studying at Columbia, and he was very friendly with Langston Hughes. I met him with Langston because Harlem was so small that when you gave a party everybody knew it, and Lorca, Federico García Lorca, was a friend of Langston's and Langston squired him around Harlem.

8 In a letter written to his parents from New York on 14 July 1929, Lorca spoke of a party he had recently attended in Harlem in which Los negros cantaron y danzaron. ¡Pero qué maravilla de cantos! Sólo se puede comparar con ellos nuestro cante jondo [The blacks sang and danced. What marvellous songs! They are only comparable to the 'deep song' of flamenco] (Epistolario Completo 626).

9 For more information on the changing reception of Lorca through English translation, see Walsh (2017).

10 The Beloit Poetry Journal informed me that they never retain copyright of the work they publish - only American serial rights, and then copyright reverts to the poet. When I contacted Simon and Schuster, the New York literary agency still responsible for the Langston Hughes estate, they had no knowledge of this translation, and when asked to check this reference, they confused it with the 1953 edition by Rolfe Humphries.

11 In his 1983 translation of the Gypsy Ballads, Cobb made the following withering and now quite racist assessment of Hughes's version:

The first translator to attempt the major ballads of the Romancero Gitano was the American Negro poet Langston Hughes [...] His translation seems deliberately formless; the phrasing is wooden, and the choice of vocabulary apparently was not given proper consideration. Published in the Beloit Poetry Journal in 1951, it has fortunately remained somewhat inaccessible.

(Cobb, 1983, x)

12 Mayhew also highlights this example in his praise of Hughes's translation (2009, 57).

13 The term 'vestments' sounds rather ecclesiastical and clearly dilutes the feminine and unequivocally homoerotic allusion inherent to Saint Michael's enaguas, which would literally mean 'petticoat.' In what was perhaps another avoidance strategy, Hughes translated the notably homoerotic efebo as 'youth' rather than as a closer equivalent such as 'Adonis.' It is worth remembering in this sense that the final version of the translation was to some extent supervised by Francisco García Lorca, who was always reluctant to countenance any suggestion of his brother's homosexuality. 
14 Daily Worker, 16 September 1936.

15 Criterion 17(66), October 1937, 153-154.

16 Stephen Spender and J.L. Gili, Poems by F. García Lorca (London, 1939).

17 In Rogers $(2012,176)$.

18 In her posthumously published memoirs, the poet's youngest sister, Isabel, would accuse Martínez Nadal of stealing manuscripts from the family residence in Madrid during the Civil War. However, perhaps knowing that Lorca's family would read his 1939 Introduction to Spender and Gili's first anthology of Lorca translations, Martínez Nadal wrote that Lorca's father was 'a wealthy farmer of great natural talent and ripe judgement' and that his mother was a 'a woman of delicate Andalusian sensibility' (1939, vii).

19 Their anthology includes translations of a few brief excerpts from Bodas de Sangre and Yerma.

20 For more information on Humphries as a translator, see Young (1999).

21 In a letter Humphries revealed that like Altolaguirre in the opposite direction, his approach to Spanish-English translation was to render the text word-for-word using a dictionary and asking more linguistically qualified friends for their advice and opinion (Gillman and Novak, 1992, 157).

22 ... And Spain Sings. 50 Loyalist Ballads. Eds. Rolfe Humphries and Mair J. Bernadette (New York: The Vanguard Press, 1937).

23 The fact that this was a politically motivated edition is evinced by the fact the editor Norton categorically told Bergamín he was not publishing the book for economic reasons when the latter asked him for royalties (see Eisenberg, 1976, 85).

24 In a letter to his friend Louise Bogan, Humphries (in Eisenberg, 1976a, 58-59) would opine:

The New York stuff is pretty much on the surrealist side and I seem to detect in Lorca a show off bad kind of bohemianism around that period, which I don't like so much [...] I don't like his later poetry very much; there will be a fine passage now and then, but in general I think the new world, and New York, were rather too much for him, and the surrealist stuff got up his nose too much [...] that surrealist smarty side [...] gets more boring as time goes on [...] And the New York poems still sound pretty hysterical.

25 'Federico's American friends were necessarily somewhat selective in presenting the poet to other people. It was not always easy to entertain a guest who spoke no English' (Adams, 1977, 123).

26 In 2010, the complete original text was republished in facsimile edition by the Federico García Lorca Museum and the Diputación de Granada [Granada Provincial Government] with a Preface by Antonio Muñoz Molina.

27 In a review in The New Republican, he would state that 'there has been no more terribly acute critic of America than this steel-conscious and deathconscious Spaniard [...] he hated us, and rightly, for the right reasons.'

28 'No procede su autorización. Se trata de un estudio literario sobre las influencias populares en la obra de Lorca en temas concretos como política, el sexo, la muerte y el arte. Los ataques al régimen actual son constantes y la Iglesia y el Catolicismo español tampoco salen bien parados. Este autor que debe ser un exiliado político interpreta también la guerra de Liberación desde el otro lado y barriendo hacia dentro. Se propone la denegación de su importación. Madrid, 16 de septiembre de $1957^{\prime}$ [No authorization granted. This is a literary study of the popular 
influences in the work of Lorca in relation to specific questions such as politics, sex, death and art. It contains constant attacks on the current regime and the Church and Spanish Catholicism are also heavily criticized. This author, who must be a political exile, also interprets the war of Liberation from the other side and is very biased. Its importation should be rejected. Madrid, 16 September 1957].

$29 \mathrm{He}$ also translated a series of Spanish Golden Age plays for the BBC, which were published posthumously in 1959, as well as works by Baudelaire and Eça de Queiroz.

30 In an article devoted to Lorca's 'afterlives,' Noel Valis (2014) states in reference to this poem by Roy Campbell that 'as a translator, he was keenly aware of the lethal effects of bad translation, though here he is also satirizing the stereotypical martyr image attached to Lorca' (293).

31 One of the many instances of Campbell's propensity to Hispanic mythmaking is the claim that he learnt Spanish with the help of the great Nicaraguan poet Rubén Darío, who he purportedly met in a bar in Barcelona in 1934. Bearing in mind the fact that the latter had died in his homeland in 1916, we can see the need to exercise caution in regard to any biographical details provided by Campbell, particularly those related to his experiences in Spain.

32 'For the rest of his life Campbell was to claim that he fought for Franco. So he did, with his pen. But his actual experience of the battlefield was confined to this tour by car on the single day of 1 July 1937' (Alexander, 320).

33 See Alexander $(1982,21)$.

34 This foreword to Poems by F. García Lorca, translated by Stephen Spender and Joan Gili, which was so deeply troubling to Republican exiles as we shall now see, had been removed by the time this volume was republished in 1943 and replaced by a brief introduction by the two translators.

35 De Torre was not only a personal friend of Lorca, but as early as 1938 he had also edited the first version of his Obras Completas, which were published by Losada in Buenos Aires.

36 Eisenberg $(1987,87)$.

37 Eisenberg $(1987,88)$.

38 Francisco García Lorca was the Spanish Vice-Consul in Tunis in 1934 before becoming Consul in Cairo the following year.

39 Eisenberg $(1987,90)$.

40 Alexander $(1982,218)$.

41 Alexander (1982, 226-227).

42 A selection of these Lorca translations eventually appeared in 1985 in Volume II of Campbell's Collected Works.

43 Curiously, this series also included a book about Unamuno by Arturo Barea, who, as we have seen, was instrumental in ensuring that Campbell's translations were rejected by the Lorca family.

44 Spender (1949, 331-332).

45 Spender $(1943,8)$.

46 This choice of word was clearly designed to antagonize Communists, for whom the kulaks were anathema, and labelling Lorca as one was therefore a quite deliberate provocation. He later quite pointedly also refers to Lorca as 'the son of landowning gentry' $(1952,9)$.

47 See García Montero (2016) for a complete study of Lorca's readings in both Spanish and other literatures. 
48 Christopher Maurer has written of how

Campbell's Lorca - who had grafted (country know-how!) Baroque Spanish poetry onto the popular oral tradition - the Lorca who meshed with Campbell's vision of a 'timeless, bucolic Spain', had gone astray, down the path of homosexuality, under 'the influence of Whitman.

$(2019,39)$

49 According to Campbell, 'Lorca [...] had known intense suffering in childhood and throughout the rest of his life, since he was never to know the normal command of his muscles and limbs' $(1952,27)$.

50 'The Civil Guard are actually a corps d'élite who lost about eighty percent of their personnel during the Civil War. They wear tri-corned hats and blue capes and are great fighters. They are detested by the gipsies as they uphold order on the country roads and are interested in keeping down the theft of horses and poultry to which the gipsies are partial' (58).

51 This distortion belies the fact that Lorca was in fact sued over this composition by a member of the Civil Guard and was extremely worried about its repercussions, justifiably so as it has often been cited as one of the many possible reasons for his murder in Granada.

52 For example, in the 'Romance Sonámbulo' when Lorca writes, 'Compadre, quiero cambiar mi caballo por su casa,' Campbell overtranslates this as, 'Companion, I should like to trade my pony for your house and grange,' thus forcing the rhyme with 'change' and increasing the numbers of syllables in English to fit his chosen metre.

53 According to Campbell, 'The figure of Saint Christopher is used in Spanish to describe any extremely hirsute, muscular, vigorous and swarthy type of person' (42). I have been unable to find any written or oral evidence for this assertion.

54 The term 'mephitic' (noxious or foul-smelling) seems to have been a keyword in his depiction of Lorca, and we have already seen how he used it in his homophobic outburst in Flowering Rifle.

55 Even Lorca's close friend, the Chilean diplomat Carlos Morla Lynch, would perpetuate these versions in his heavily excised memoir entitled En España con Federico García Lorca [In Spain with Federico García Lorca], which was first published in 1957 and in which he refers to Lorca variously as 'un gran niño andaluz' [a giant Andalusian child] (Morla Lynch, 2008, 39).

56 Campbell's book was reviewed on 21 December 1952 and Humphries's version of the Gypsy Ballads on 14 June 1953.

1 The quote is from the inner dust jacket of Mayhew (2009).

2 Curiously, of the five poems from Poet in New York included in this volume, only one of them is accompanied by Belitt's translation and the other four are by Spender and Gili.

3 See Mayhew (2009) for a detailed analysis of the adoption and the kitsch reduction of the duende in US poetry.

4 Accessed 23 December 2019. https://poetrysociety.org/features/tributes/ susan-wheeler-on-ben-belitt

5 A fellow granadino and the brother of Lorca's own brother-in-law, Manuel Fernández Montesinos, the Socialist mayor of Granada, who, like Lorca, was murdered at the outbreak of the Civil War in the city. 
6 This version has not been without its advocates, and, as late as 1990, Honig $(1992,22)$ would still feel the need to acknowledge 'our debt' with Ben Belitt as 'ese extraordinario poeta americano, cuya traducción de Poeta en Nueva York ha mantenido vivo en América el espíritu de Federico García Lorca durante los pasados treinta y cinco años' [that extraordinary American poet, whose translation of Poet in New York has kept alive in America the spirit of Federico García Lorca during the last thirty-five years] and further state that 'criticar una traducción por ser 'demasiado libre' o por 'tomarse libertades' es negar la posibilidad de crear un verdadero poema' $(1992,20)$ [criticizing a translation for being 'too free' or for 'taking liberties' is denying the possibility of creating a real poem].

7 For example, in the 'Ode to Walt Whitman,' Lorca writes: 'el cielo tiene playas donde evitar la vida / y hay cuerpos que no deben repetirse en la aurora.' A simple, literal rendering would be 'Heaven/The Sky has beaches where life can be avoided /and there are bodies that should not be repeated at dawn,' the latter image seeming to be a clear reference to the frustrating impossibility of procreation for homosexual men like Federico García Lorca. Nevertheless, in one of his characteristic flights of overtranslational fancy, Belitt translated these two verses as: 'Heaven has shores for our flights out of life / and the corpse need not make itself over at dawn.'

8 https://allenginsberg.org/2014/01/expansive-poetics-23-lorca-4/

9 Pages 768-769 of the Collected Poems (1947-1997) of Allen Ginsberg.

10 Accessed 12 October 2019. https://allenginsberg.org/2014/02/expansivepoetics-24-lorca-on-dali/

11 Accessed 12 October 2019. http://ginsbergblog.blogspot.com/2011/12/ garcia-lorca-allens-1975-naropa-class.html

12 See Gibson $(2016,416)$.

13 Accessed 12 October 2019. https://allenginsberg.org/2014/01/expansivepoetics-20-lorca-1/

14 Accessed 12 October 2019. https://allenginsberg.org/2014/01/expansivepoetics-20-lorca-1/

15 Accessed 12 October 2019. https://allenginsberg.org/2014/01/expansivepoetics-21-lorca-2/

16 Accessed 21 July 2019. www.poetryfoundation.org/poets/philip-levine

17 For more information on the literary relationship between Federico García Lorca and Philip Levine, see Antolín Lagunilla (2002).

18 According to Elianna Kan, 'I first met Philip Levine thanks to Lorca. In June 2013, I was helping organize an event to celebrate the exhibition of the original manuscript of Poet in New York at the New York Public Library, and I'd invited Levine to participate. It wasn't easy getting him to join us. You might even say he was cantankerous. He had a lot of questions about the evening: How many readers were there going to be? How long would the event last? Which specific texts were going to be read? He was particularly annoyed when he'd heard that an actor would be performing Lorca's lecture 'A Poet in New York,' insisting that the lecture, much less a dramatic reading of it, did no service to the poet. But after numerous phone calls and e-mails, Levine reluctantly agreed to take part in the event, though he made clear it would only be 'in his own way.' He insisted, in the meantime, that I read his essay 'The Poet in New York in Detroit. In www.theparisreview.org/ blog/2015/02/23/my-lost-poet/. Accessed 20 November 2019.

19 www.theatlantic.com/magazine/archive/1999/04/an-interview-withphilip-levine/308619/

20 In Mayhew $(2009,161)$. 
21 According to Christopher Maurer,

When I first edited Collected Poems, Suites was much less known than other books, had not been studied carefully, and its textual relation with Songs was a little fuzzy [...] Jerry Rothenberg and I went through several versions of his Suites --back and forth by mail-- until we were both more or less happy with them. Though I was aware of the inconsistency (no such prefaces to other books), it seemed a good idea. As Mayhew points out, his approach was quite different from that of others, and it did not seem unreasonable to make space for a few words of explanation. If I had the book to do over again, I would have had everyone do a short --300 word-translator's preface, perhaps preceding the notes, at the back of the book?

Source: e-mail from Christopher Maurer to the author, 21 December 2019.

22 'When he first approached the Lorca estate in 1966 with the idea of translating the play (at the request of the original Lincoln Center Theater), it granted Merwin permission for a limited number of performances. No other rights, including publication, were granted' (Bensussen, 1994, viii).

23 See James Wright. A Life in Poetry. Ed. Jonathan Blunk (New York: Farrar, Straus and Giroux, 2017), 109.

1 In F.G.L Autógrafos II: El Público (Oxford: Dolphin Press).

2 See https://elpais.com/diario/1986/06/04/cultura/518220002_850215.html. Accessed 19 December 2019.

3 Among other questionable information, she informs her reader that 'Lanjarón and San Vicente' are both 'farm villages on the plain, all of them within reach of the Moorish vestiges of Granada' (11). There is no such village as 'San Vicente,' which instead was the name of the Lorca's family residence in what was then the countryside on the outskirts of Granada, a residence named in honour of the poet's mother, Vicenta. And Lanjarón is most certainly neither on the plain nor 'within reach of the Moorish vestiges of Granada.' It is actually a spa town high up in the mountains at the entrance to the Alpujarras mountains and is some considerable distance from the city of Granada, some 45 kilometres (nearly 28 miles), which in the late 1920s when Adams visited Lorca in Granada would have been a long and tiring trip.

4 It is unclear who Mildred Adams was referring to in the case of the African-American writer who went 'more than once' to Harlem with Lorca, but it is tempting to hazard a guess that due to the additional similarity of their respective surnames that she was confusing Himes with Langston Hughes.

5 It is not clear who this 'English poet' may have been, and El Público was not translated and performed professionally in English until 1988. The American poet Carlos Bauer translated the play in 1983, but the first UK version was the controversial production of the translation by the English writer Henry Livings in 1988, whose scandalous political repercussions we have discussed previously.

6 Irving Wardle from The Independent was also unconvinced by this adventurous cultural transposition and the withering title of his review effectively sums up the overall impression created by this 'Lancashire version' of Bodas de Sangre: 'Maladies are made of this.' Accessed 7 October 2019. www.independent.co.uk/arts-entertainment/theatre-maladies-are-made-ofthis-1431950.html

7 In Delgado $(2008,112)$.

8 In Delgado $(2008,112)$.

9 For a more complete analysis of this question, see Edwards $(2000,722-723)$. 
10 In his famous 'I have a dream' speech of 1963, Martin Luther King still resolutely used the word and it was not until the 1970s that the term first became truly problematic and then gradually came to be considered unacceptable.

11 Curiously, in his aforementioned paper read in 1990, White $(1992,38)$ already warned of the inevitable tendency for a text to become obsolete and stated that 'if it's lucky it will only last thirty years.'

12 This new revised edition includes some very minor modifications in the text in the light of the appearance of the aforementioned definitive manuscript, none of which affects the sensitive racial and sexual language which is the object of this study.

13 Interestingly, as early as 1939 , Spender and Gili also opted to render maricas as 'pansies.'

1 Faggots of the world, slaves of women / bitches of their boudoirs.

2 See Sahuquillo $(2007,236)$.

3 Accessed 14 October 2019. https://elpais.com/diario/1998/06/11/cultura/ 897516001_850215.html

4 Accessed $1 \overline{4}$ October 2019. https://elpais.com/diario/1998/06/12/cultura/ 897602404_850215.html

5 As one wag archly noted, with the post-Franco PSOE (the Spanish Socialist Party) governments of Felipe González, the country experienced the 'normalización' of its culture, whereas with the subsequent right-wing Popular Party governments of José María Aznar, Spain underwent the 'normaduvalización' of its culture, an untranslatable pun based on the name of the famous Spanish vedette Normal Duval who was well known for her decidedly low-brow, mildly erotic 'destape' cabaret shows and robustly right-wing political sympathies.

6 See Gibson (2009, 33).

7 The translations in question are by Stephen Spender and J.L. Gili (1939), Rolfe Humphries (1940) Ben Belitt (1955)), Jack Spicer (1957), Stephen Fredman (1975), Greg Simon and Steven F. White (1988, revised edition published in 2013, Carlos Bauer (1988), Merryn Williams (1992), A.S. Kline (2007), and Pablo Medina and Mark Statman (2008).

8 The manuscript is dated 15 July 1930, by which time Lorca had already returned to Spain from New York via Cuba, where the poem is believed to have been largely written. This period of composition would also coincide with his writing of El Público [The Public], a text that Lorca himself referred to as a play with a 'frankly homosexual subject' and one with which this ode bears strong parallels in terms of its theme of homoerotic self-loathing.

9 See for example Stainton (1998, 259) and Manrique (1998, 73).

10 Gerardo Diego, Antología (Madrid, 2007, 787-788).

11 See for example Paul Binding (1985). The text was subsequently translated into Spanish in 1987.

12 See Poeta en Nueva York. Ed. María Clementa Millán (Madrid, 1987, 287).

13 Due to the fact that part and parcel of any translation is an inevitable, although undesirable, tendency to become obsolete (only with good fortune will it last thirty years), the translator often feels drawn towards modernizing the text and assimilating it properly to a contemporary public.

14 Eshleman $(1977,38)$.

15 For a detailed analysis of Spicer's approach and motivation, see Eric Keenaghan, 'Jack Spicer's Pricks and Cocksuckers,' The Translator, 4, 1998.

16 Luis Cernuda 'Federico García Lorca (1898-1936)' in Prosa I (Madrid, 2002, 212). 
17 María M. Delgado states that Ian Gibson 'now enjoys something of the role of custodian: widely consulted and quoted on matters pertaining to the poet's inheritance and visibility. It is not insignificant that one critic labelled 1998 not Lorca's year but Gibson's' $(2008,198)$.

18 Ian Gibson, Vida, pasión y muerte de Federico García Lorca (Madrid, 2016, 456).

19 Francisco Umbral, Lorca, poeta maldito (Madrid, 2012, 188).

20 Anna E. Hiller has attempted a similar analysis in 'Queer Geographies: Federico García Lorca's “Oda a Walt Whitman” in English Translation,' a study which examines just five translations of the poem and does not include either Rolfe Humphries' version of the poem included in the 1940 edition princeps of Poet in New York or the seminal 'Beat Generation' version translated by Ben Belitt in 1955, in addition to stating that the publication date of the Spender and Gili translation is 'unknown.' The aforementioned study also focuses expressly on the geographical nature of the queer references in the poem and their resistance to translation. See Spanish and Portuguese across Time, Place and Borders, ed. Laura Callaghan (London, 2014, 20-35).

21 Although Hiller defends this decision and states that

it can be inferred that the use of the term marica would be recognizable in a wider variety of contexts, both English and Spanish speaking, and can therefore be seen as having a more universalizing effect in the language of the poem.

22 Due to the well-known textual controversy surrounding Poet in New York, Spender and Gili translated the verse that appears in José Bergamín's 1940 Séneca edition of the poem (los maricas, Walt Whitman, te soñaban), although in later bilingual republications of their translation, such as the Selected Poems edited by Francisco García Lorca and Donald M. Allen, the Norton version of the verse appears which makes the reference to dreaming rather confusing and reflects a considerable shift in the attitude of the 'maricas' towards Whitman, which would now seem to be one of benevolent admiration.

23 The term 'mephitic' (noxious or foul-smelling) seems to have been a keyword in his depiction of Lorca, and we have already seen how he used it in his homophobic outburst in Flowering Rifle.

24 Hughes was the author of poems entitled 'Ballad of the Gypsy,' 'Gypsy Man,' and 'Gypsies,' in which he wrote the following truly Lorquian verses: 'The gypsies' skins are olive-dark / The gypsies' eyes are black fire.'

25 Accessed 23 October 2019. https://allenginsberg.org/2014/01/expansivepoetics-20-lorca-1/

26 In 2019, Lorca's 'unfinished play' was at last given a final scene by the young Spanish playwright Alberto Conejero. This new version opened at the Teatro Español in Madrid, in January 2019. Combining the original and incomplete text with fragments from Poeta en Nueva York and Lorca's own personal correspondence as well as new text by Conejero himself, the production was extremely well received but as yet has not been translated.

27 The production was by the London Classic Theatre Company at Southwark Playhouse.

1 'New York seems horrible and that's why I'm going there.' (Letter from Lorca to his friend the Chilean diplomat Carlos Morla Lynch.) 
2 In 2019, The New York Public organized a very successful (and sold out) event called 'Federico García Lorca \& Lou Reed: A Celebration of Two Poets in New York.' The event was 'labelled as a night of readings and discussion to celebrate the 30th anniversary of Reed's 1989 New York album and the 90th anniversary of García Lorca's 1929 visit to NYC that resulted in his Poet in New York book.' See: www.nypl.org/events/programs/2019/11/20/ federico-garcia-lorca-lou-reed-celebration-two-poets-new-york? nref $=56896$. Accessed 23 December 2019.

3 The composition was entitled The Wind Remains and was directed in 1943 by Leonard Bernstein. During the 1950s, Bowles also composed an opera version of Yerma (which was never performed due to copyright reasons) and also composed music for four poems from Canciones. For more information about Bowles's creative interest in Lorca, see: https://elpais.com/ cultura/2010/04/06/actualidad/1270504802_850215.html. Accessed 26 October 2019

4 https://elpais.com/diario/1998/05/15/andalucia/895184548_850215.html. Accessed 10 December 2019.

5 The extraordinarily moving speech in which an aged Cohen paid homage to Lorca and Spanish culture can be found at: https://www.abc.es/cultura/ musica/abci-emocionante-discurso-leonard-cohen-entrega-premios-principeasturias-201611111021_noticia.html. Accessed 24 January 2020.

6 For the most complete study of Lorca's US reception, see Mayhew (2009).

7 The documentary has been exhaustively analysed by Stefan Schreckenberg (2006).

8 See Schreckenberg (2006, 232-235).

9 In a letter to Jorge Guillén dated 20 November 1929, Pedro Salinas wrote that he had received 'de Federico una carta tipo bachillerato: 'todo muy bonito, tengo muchos amigos, ya sé hablar inglés, etc' [from Federico a high school style letter: everything is very pretty, I have lots of friends, I already know how to speak English, etc]. My translation (in Maurer and Anderson, $2013,66)$. This parodic version is very similar in tone to a letter that Lorca also wrote to Melchor Fernández Almagro, an old friend from Granada, on 30 September 1929, in which he told him, 'Tengo muchas amigas americanas y muchos amigos y, por tanto, adelanto en el inglés rápidamente' [I have plenty of American female friends and many other friends, so I'm learning English quickly]. My translation (in Maurer and Anderson, 2013, 65).

10 According to Leslie Stainton, Lorca's lecture on New York was 'more fiction than fact' (298).

11 When attending Midnight Mass with some American friends in New York on Christmas Eve 1929, according to Mildred Adams

only Federico could feel entirely at home in the glory and pomp of the service. And this he did, with praises for this evidence of Catholicism in 'Babylonic' New York which, in view of his declared anti -clericalism, were surprising.

(Adams, 1977, 125)

12 In a letter to his family dated 8 August 1929, Lorca wrote that 'Pero sigo diciendo que la belleza y la profundidad del catolicismo es infinitamente superior. De ser religioso en una religión positiva no hay más perfección que en el catolicismo' [I still say that the beauty and profundity of Catholicism is infinitely superior. If one is going to be a practicing member of a positive religion, there is none more perfect than Catholicism' (Maurer and Anderson, 2013, 37). 
13 Interview at the Residencia de Estudiantes in Madrid on 7 March 2018.

14 Back Tomorrow Programme. Page 3.

15 Accessed 22 December 2019. /elpais.com/cultura/2008/07/02/actualidad/ 1214949605_850215.html

16 'I was lucky enough to see with my own eyes the last crash in which several billion dollars were lost: a real tumult of dead money that just slid into the sea [...] among several suicidal, hysterical people and groups of people fainting [...] it was a terrible spectacle and without any grandeur.'

17 'I understood that they had murdered me/ They searched the cafés and the cemeteries and the churches, they opened coffers and closets, they destroyed three skeletons to tear out their gold teeth. But they never found me. They never found me? No. They never found me.'

18 'Los niños de Cristo dormían y el judío ocupó su litera. Tres mil judíos lloraban en el espanto de las galerías' [The children of Christ were sleeping and the Jews were crying in the horror of the galleries]. See Glass (1982) and Nordlund (1998) for a detailed analysis of 'Cementerio Judío.'

19 'Y las brisas de largos remos/golpeaban los cenicientos cristales de Broadway ... Que ya las cobras silbarán por los últimos pisos,/que ya las ortigas estremecerán patios y terrazas, / que ya la Bolsa será una pirámide de musgo,/ que ya vendrán lianas después de los fusiles/y muy pronto, muy pronto, muy pronto.¡Ay, Wall Street!' [And the breezes of long oars struck the ashen glass of Broadway ... Because the cobras will whistle in the highest floors, because the nettles will frighten rooftops and terraces, because the Stock Market will be a pyramid of moss, because reeds will come after rifles and very soon, very soon, very soon. Oh, Wall Street!].

20 Curiously, Statman is also the author of a poem entitled 'Translating García Lorca,' which debates the shadow that translating these poems cast over his own work.

21 'The goal became how to take the language that Lorca wrote in - which looks remarkably like Spanish but is really a language called Lorca - and render that into a language that looks remarkably like English but remains, again, a language called Lorca' (Medina and Statman, 2008, xix).

22 'Lorca went and stayed in the U.S.A. for some time [...] The result on his poetry was entirely negative [...] In Lorca's New York poems, the Poeta en Nueva York, his metaphors and images fall out of focus; his verse becomes loose, plaintive, and slightly mephitic' (Campbell, 1952, 71).

23 Poeta en Nueva York. Gutenberg: Barcelona (2013). This text can now be considered the canonical Spanish original text, following the appearance of the original manuscript in 1999 and its acquisition by the Federico García Lorca Foundation at an auction in 2003.

1 'I am totally Spanish and for me it would be impossible to live outside my country; but I hate those who are Spanish just for the sake of it, I am a brother to everyone [...] I sing Spain and I feel Spanish to my core; but above all I am a citizen of the world and a brother to everybody.'

2 Accessed 18 December 2019. www.nytimes.com/2000/07/04/books/poeticlove-affair-with-new-york-for-garcia-lorca-city-was-spiritual-metaphor. html

3 The text of the conference has currently not been published, although a summary can be found at the following site: www.nypl.org/events/programs/ 2013/07/09/lorca-jews-and-african-americans-romance-racism-or-simplemisunderstanding. Accessed 26 October 2019. 
4 Even though it was coined in academic use as early as the 1980s in relation to the study of colonialism, its current ubiquity is a relatively recent phenomenon, and it was added to the Oxford English Dictionary only in 2017 and also starts to appear regularly in the English-language press from 2015 onwards.

5 In a letter written to his parents from New York on 14 July 1929, Lorca spoke of a party he had recently attended in Harlem in which 'Los negros cantaron y danzaron. ¡Pero qué maravilla de cantos! Sólo se puede comparar con ellos nuestro cante jondo' [The blacks sang and danced. What marvellous songs! They are only comparable to the 'deep song' of flamenco] (Epistolario Completo, 626). My translation.

6 Isabel Soto quotes Richard Barksdale's biography of Langston Hughes, in which the former refers to Lorca as 'a friend and fellow poet' of Hughes and also provides a quote from the Harlem Renaissance artist Romare Bearden which unequivocally states that the two poets were friends:

Lorca was studying at Columbia, and he was very friendly with Langston Hughes. I met him with Langston because Harlem was so small that when you gave a party everybody knew it, and Lorca, Federico García Lorca, was a friend of Langston's and Langston squired him around Harlem.

7 'New York is a meeting place for every race in the world, but the Chinese, Armenians, Russians, and Germans remain foreigners. So does everyone except the blacks. There is no doubt but that the blacks exercise great influence in North America, and, no matter what anyone says, they are the most delicate, spiritual element in that world' (Maurer and Anderson, 2013, 135, 139).

8 In 1980, Baraka gave an apologetic interview to The Village Voice called 'I was an Anti-Semite.'

9 Although he was by no means consciously anti-Semitic, Lorca could undoubtedly be rather naive in terms of the potentially offensive nature of his reference to Jews in his work. A clear example of this can be found in a 1933 interview with a Bueno Aires-based Jewish magazine, in which he tried to mitigate the offence caused by references to 'Jewish executioners' and 'rude Jews' in his play La zapatera prodigiosa [The Shoemaker's Prodigious Wife] by stating that 'Jew' was a 'traditional term of insult in rural Andalusia.' According to Stainton, 'Despite his lifelong protestations of sympathy for the oppressed, Lorca seemed oblivious to the impact of racist language' (Stainton, 1998, 357-358).

10 For more information on this question, see the following newspaper article by Ian Gibson: http://blogs.publico.es/apuntesperipateticos/181/lorca/. Accessed 16 June 2019.

11 'I believe that being from Granada leads me to understand and empathize with those who are persecuted. With Gypsies, Blacks, Jews [...] with the Moorish exile that we all have inside us.' In Obras Completas, III, 503.

12 See Umbral $(2012,158)$ for an analysis of what he calls Lorca's 'inverse racism.'

13 The polysemic nature of the term judias in Spanish has even led some translators of this poem to opt for a rather bizarre and literal rendering of the word as 'the little French beans' or 'the little haricot beans.' As the context, clearly expressed in the three preceding lines, is that of violence against the presumed enemies of the blacks and Lorca refers to judios and judias as participants in this oppression, it is extremely hard to justify this reading: 
According to Sager $(1999,86)$

we must assume that two of the translators Merryn Williams and J. L. Gili, deliberately ignore the context when they introduce vegetables into this line, presumably influenced by «manzana» (apple) in the line above. We should exclude the possibility that they did not know both meanings of the word because any dictionary would have listed both meanings.

14 In his famous 'I have a dream' speech of 1963, Martin Luther King still resolutely used the word, and it was not until the 1970s that the term first became truly problematic and then gradually came to be considered unacceptable.

15 Indeed, this very question has led to several high-profile incidents in the world of sport in Spain and the UK, one of which saw professional translators called into court to offer their considered opinion on the correct dynamic equivalence of the term 'negro' as used by the Uruguayan soccer player to a black opponent (see also Marías, 2004).

16 'Does the translator deconstruct or reconstruct the Americans from Africa, the Jews and the homosexuals who inhabits an urban landscape that seems eternally familiar? Is the solution a sheen of old-fashioned language or a hopeless addition to the imperative: "Make it new!" '(1992, 38). 'Make it New!' was famously Ezra Pound's dictum regarding translation.

17 The original title of a 2017 film version, And Then There Were None, was once again translated into Spanish as Diez Negritos. The novel was first published in the UK with the aforementioned offensive title, which was immediately changed by the US publishers in 1940. It was not changed in the UK until 1985. although in the United States the first offensive title was never used, evincing the vastly different racial sensitivities and history of the two countries.

18 See Ortega (1986).

19 Accessed 20 December 2018. www.elmundo.es/papel/cultura/2018/09/17/ 5b9e799be2704ea8af8b465b.html.

1 'For a poet death is victory;/A demonic wind pushes him through life/And if a blind force/with no understanding of love/Turns you the poet through a crime into a hero.' Luis Cernuda, 'Elegy to a Dead Poet. F.G.L.'

2 See Paul Julian Smith, 'The Lorca Cult. Theatre, Cinema, and Print Media in 1980s Spain,' The Theatre Review, 7(4), 1998.

3 Accessed 12 November 2019. www.nytimes.com/2017/10/30/books/reviewpoet-in-spain-federico-garcia-lorca-sarah-arvio.html

4 As Lorca made Whitman an embodiment of his own poetic spirit, so we translators become the embodiment of Federico García Lorca having devoted years to the task of shaping him into English, thereby creating his own profile as an American poet.

1 Several translations of the plays have been through various editions. Here I just give the first reference of the publication of the text, unless the edition is clearly indicated as a revised one. In the case of the major anthologies edited by Christopher Maurer, there have been some textual modifications and, therefore, I give all of the years of publication. I have included the online versions that I have been able to trace, but these are constantly increasing and, by their very nature, are harder to keep a bibliographical track of as sometimes the link ceases to exist. When the text has not been published, but there is some written record of the performance, the reference given is that of the performance. Finally, the year given for the works by Lorca is that of the first complete publication, although many of the texts had been composed several years before. As is well known, Lorca was notoriously loath to submit his texts to press in a final, definitive version. 


\section{Bibliography}

Adams, Mildred. 1977. García Lorca. Playwright and Poet. New York: George Braziller.

Alexander, Peter. 1982. Roy Campbell. A Critical Biography. Oxford: Oxford University Press.

Allen, Donald and Francisco García Lorca, eds. 1955. The Selected Poems of Federico García Lorca. New York: New Directions.

Alonso, Dámaso. 1962. 'Lorca and the Expression of the Spanish Essence' in Lorca: A Collection of Critical Essays, ed. Manuel Durán. Englewood Cliffs, NJ: Prentice Hall, 50-56.

Anderson, Andrew A. 2013. Introduction to Poeta en Nueva York. Barcelona: Galaxia Gutenberg.

Anderson, Andrew A. 2018. 'La trayectoria de 'Poeta en Nueva York' a través de sus traductores estadounidenses: Humphries, Belitt, Simon/White y después' [The Trajectory of Poeta en Nueva York through Its US Translators: Humphries, Belitt, Simon/White and Afterwards] in El impacto de la metrópolis. La experiencia americana en Lorca, Dali y Buñuel [The Impact of the Metropolis. The American Experience in Lorca, Dalí and Buñuel], ed. Jose M. del Pino. Madrid: Editorial Iberoamericana, 91-113.

Antolín Lagunilla, Marco Antonio. 2002. Federico García Lorca y Philip Levine. Historia de dos poetas y dos países [Federico García Lorca and Philip Levine. A history of two poets and two countries]. Unpublished Doctoral Thesis, Universidad de Valladolid.

Antolín Lagunilla, Marco Antonio. 2005. 'La influencia de Federico García Lorca en Philip Levine: el descubrimiento de una nueva poesía', Boletín de la Fundación Federico García Lorca, 35-36, 33-53.

Barea, Arturo. 1944. Lorca. The Poet and his People. London: Faber and Faber.

Barea, Arturo. 2018. Lorca. El Poeta y su Pueblo. Madrid: Instituto Cervantes Colección Los Galeotes.

Bauer, Carlos.1992. 'Cómo traducir a Lorca: algunas ideas sueltas' [How to Translate Lorca, a Few Ideas], Boletín Fundación Federico García Lorca, 6, 10-11, 41-43.

Belitt, Ben. 1955. 'Translator's Foreword' in Poeta en Nueva York. New York: Grove Press, xl-xlv.

Benardete, M.J. and Rolfe Humphries, eds. 1937. And Spain Sings. Fifty Loyalist Ballads Adapted by American Poets. New York: The Vanguard Press. 
Benjamin, Walter. 2002. 'The Task of the Translator' in Walter Benjamin. Selected Writings. Volume 1 1913-1926, eds. Marcus Bullock and Michael W. Jennings. Cambridge, MA: Harvard University Press, 253-263.

Bensussen, Melia. 1994. Introduction to Blood Wedding and Yerma. New York: TCG Translations, Vii-Xii.

Bergamín, José. 1940. 'Death at Dawn. Night of Blood and Tears' Introduction to The Poeta en Nueva York and Other Poems of Federico García Lorca. New York: W.W. Norton \& Company Inc, 9-15.

Binding, Paul. 1985. Lorca. The Gay Imagination. London: GMP Publishers.

Bonaddio, Federico, ed. 2007. A Companion to Federico García Lorca. London: Boydell and Brewer.

Brickell, Herschel. 1940. 'Federico García Lorca. A Biographical Note' in The Poeta en Nueva York and Other Poems of Federico García Lorca. New York: W.W. Norton \& Company Inc, 206-209.

Callahan, David. 1994. 'Negotiating Spanish Poets in English: 1920-1940', Dedalus: Revista Portuguesa de Literatura Comparada, 3-4, 155-168.

Calvo, Antonio F. 2007. Traducción e interpretación: Langston Hughes y Federico García Lorca, encuentro en el lenguaje [Translation and interpreting: Langston Hughes and Federico García Lorca, encounter in language]. PhD Diss. City University of New York.

Campbell, Roy. 1939. Flowering Rifle: A Poem from the Battlefield of Spain. London: Longmans, Green \& Co.

Campbell, Roy.1946. Talking Bronco. London: Faber and Faber.

Campbell, Roy. 1952. Lorca: An Appreciation of His Poetry. New Haven, CT: Yale University Press.

Cañas, Dionisio. 1989. 'Lorca/Cummings: Una amistad más allá del bien y del mal' [Lorca/Cummings: A Friendship Beyond Good and Evil], Cuadernos del Norte, 52, 27-29.

Cernuda Luis. 2002. 'Federico García Lorca (1898-1936)' in Prosa I. Eds. Derek Harris and Luis Maristany. Madrid: Siruela, 206-214.

Classe, Olive. 2000. Encyclopedia of Literary Translation into English. Abingdon: Routledge.

Cobb, Carl. W. 1983. Introduction to Lorca's Romancero Gitano: A Ballad Translation and Critical Study. Jackson: University Press of Mississippi, vi-x.

Cummings, Philip. 1976. 'August in Eden', 'A Glimpse of a Man', 'The Mind of Genius' and 'The Poems' in Songs. ed. Daniel Eisenberg. Pittsburgh, PA: Duquesne University Press, 125-184.

Delgado, María M. 2008. Federico García Lorca. Abingdon: Routledge.

Doggart, Sebastian and Michael Thompson, eds. 2010. Fire Blood and the Alphabet. One Hundred Years of Lorca. Manchester: Manchester University Press.

Edwards, Gwynne. 1998. 'Lorca in the United Kingdom', Donaire, 10, 23-30.

Edwards, Gwynne. 2000. 'Productions of La Casa de Bernarda Alba', Anales de la literatura española contemporánea, 25(3), 699-728.

Eisenberg, Daniel. 1976a. Poeta en Nueva York: historia y problemas de un texto de Lorca. Barcelona: Ariel.

Eisenberg, Daniel. 1976b. Introduction to Songs. Pittsburgh, PA: Duquesne University Press.

Eisenberg, Daniel. 1987. 'Nuevos documentos relativos a la edición de Poeta en Nueva York y otras obras de García Lorca' [New Documents Related to the 
Edition of Poeta en Nueva York and Other Works by García Lorca], Anales de Literatura Española, 5, 67-107.

Eisenberg, Daniel. 2002. Lorca and Censorship: The Gay Artist Made Heterosexual. Accessed 8 October 2019. www.academia.edu/26025777/Lorca_ and_Censorship_The_Gay_Artist_Made_Heterosexual.

Eshleman, Clayton. 1977. 'The Lorca Working', Boundary, 2, 27(1), 31-50.

Fitts, Dudley. (1952, 21 December). The Voice of Lorca. New York Times. Accessed 23 September. www.nytimes.com/books/99/09/12/specials/lorcavoice.html.

Forman, Sandra and Allen Josephs. 1992. Only Mystery. Federico García Lorca's Poetry in Word and Image. Gainesville: University Press of Florida.

Frederick, Sharonah. 2013. Lorca, Jews and African Americans. Romance, Racism or Simple Misunderstanding? Accessed 21 May 2019. www.nypl.org/ events/programs/2013/07/09/lorca-jews-and-african-americans-romanceracism-or-simple-misunderstanding.

Gambier, Yves. 1994. 'La retraduction: retour et détour' [Retranslation Back and Forth], Meta, 39(3), 413-417.

Garbisu Buesa, Margarita. 2017. The Criterion y la cultura española. Poesía, música y crítica de la Edad de Plata en el Londres de las entreguerras. Kassel: Edition Reichenberger.

García Lorca, Federico. 1986. Federico García Lorca. Obras completas [Federico García Lorca. Complete Works]. Madrid: Aguilar.

García Lorca, Federico. 1997. Epistolario completo [Complete Correspondence]. Madrid: Cátedra.

García Lorca, Francisco. 1955. Introduction to The Selected Poems of Federico García Lorca. New York: New Directions.

García Montero, Luis. 2016. Un lector llamado Federico García Lorca. Madrid: Taurus.

Gibson, Ian. 1998. 'García Lorca: la breve vida de un poeta genial', El País Semanal, 1 February, 28-35.

Gibson, Ian. 2010. Lorca y el mundo gay [Lorca and the Gay World]. Barcelona: Planeta.

Gibson, Ian. 2016. Vida, pasión y muerte de Federico García Lorca [Life, Passion and Death of Federico García Lorca]. Barcelona: Penguin Random House.

Gillman, Richard and Michael Paul Novak, eds. 1992. Poets, Poetics and Politics. America's Literary Community Viewed from the Letters of Rolfe Humphries (1910-19169). Kansas: Kansas University Press.

Ginsberg, Allen. 2006. Collected Poems 1947-1997. New York: Harper Collins.

Glass, Elliot S. 1982. 'El cementerio judio: Lorca's Historical Vision of the Jews', Hispanófila, 75, 33-49.

Glauber, Robert. 1951. 'Introduction to Gypsy Ballads by Federico García Lorca', Beloit Poetry Journal, 2(1), 1-4.

Hermans, Theo. 2004. Translation in Systems: Descriptive and System-Oriented Approaches Explained. Shanghai: Shanghai Foreign Language Press.

Herrero-Senés, Juan. 2019. 'Ángel Flores, agente doble del cosmopolitismo transatlántico’ [Ángel Flores, a Double Agent for Transatlantic Cosmopolitanism], Revista de Literatura, LXXXI(161), 207-225.

Hickey, Leo. 1998. 'Pragmatic Comments On Translating Lorca', Donaire, 11, 47-53. 
Hillier, Anna E. 2014. 'Queer Geographies: Federico García Lorca’s 'Oda a Walt Whitman' in English Translation' in Spanish and Portuguese across Time, Place and Borders, ed. Laura Callaghan. London: Palgrave MacMillan, 20-35.

Honig, Edwin. 1944. García Lorca. New York: New Directions.

Honig, Edwin. 1992. 'Traducción y transfiguracion: Apartes sobre Poeta en Nueva York' [Translation and Transfiguration: Notes on Poeta en Nueva York], Boletín de la Fundación Federico García Lorca, 10-11, 19-22.

Hughes, Langston. 1993. I Wonder as I Wander. New York: Hill and Wang.

Humphries, Rolfe. 1940. 'Translator's note' in The Poeta en Nueva York and Other Poems of Federico García Lorca. New York: W.W. Norton \& Company Inc, 16-19.

Rafael Inglada. 2017. Palabra de Lorca. Declaraciones y Entrevistas Completas. Barcelona: Malpaso.

Johnston, David. 1989. Introduction to Blood Wedding. London: Hodder \& Stoughton.

Johnston, David. 1998. 'Translating García Lorca: The Importance of Voice', Donaire, 11, 54-60.

Kaufman, Bob. 1996. Cranial Guitar. Minneapolis: Coffee House Press.

Keenaghan, Eric. 1998. 'Jack Spicer's Pricks and Cocksuckers', The Translator, 4, 273-294.

Kutzinski, Vera M. 2012. The Worlds of Langston Hughes: Modernism and Translation in the Americas. Ithaca, NY: Cornell University Press.

Lefevere, André. 2017. Translation, Rewriting and the Manipulation of Literary Fame. Abingdon: Routledge.

Manrique, Jaime. 1998. Eminent Maricones. Arenas, Lorca, Puig and Me. Madison: University of Wisconsin Press.

Marías, Javier. 2004. Traducción y racismo [Translation and Racism]. Accessed 21 May 2019. http://elpais.com/diario/2004/12/12/eps/1102836419_850215. html.

Martín, Eutimio. 1986. Federico García Lorca, heterodoxo y mártir. Análisis y proyección de la obra juvenil inédita. Madrid: Siglo XI.

Martínez Nadal, Rafael. 1939. Introduction to Poems. F. Garcia Lorca. Trans. Stephen Spender and J.L. Gili. London: Dolphin Press, vii-xxvi.

Maurer, Christopher. 1991. Introduction to the Collected Poems of Federico García Lorca. New York: Farrar, Straus, Giroux.

Maurer, Christopher. 1992. 'Traduciendo a García Lorca' [Translating García Lorca], Boletín de la Fundación Federico García Lorca, 10-11, 15-17.

Maurer, Christopher. 2007. 'Poetry' in A Companion to Federico García Lorca, ed. Federico Bonaddio. London: Boydell and Brewer, 16-38.

Maurer, Christopher. 2013. Introduction to the Revised Edition of Poeta en Nueva York. New York: Farrar, Straus, Giroux.

Maurer, Christopher. 2018. 'Nueva York en una familia: una conversación con Laura García Lorca' in El Impacto de la Metrópolis: la experiencia americana en Lorca, Dali y Buñuel [The Impact of the Metropolis. The American Experience in Lorca, Dalí and Buñuel], ed. Jose M. del Pino. Madrid: Editorial Iberoamericana, 325-334.

Maurer, Christopher. 2019. 'From Country to City: Three Versions of Poeta en Nueva York' in Avenues of Translation: The City in Iberian and Latin American Writing, eds. Regina Galasso \& Evelyn Scaramella. Lewisburg: Bucknell University Press, 32-51. 
Maurer, Christopher and Andrew A. Anderson, eds. 2013. Federico Garcia Lorca en Nueva York y La Habana: Cartas y recuerdos [Federico Garcia Lorca in New York and Havana: Letters and Memories]. Madrid: Galaxia Gutenberg.

Mayhew, Jonathan. 2009. Apocryphal Lorca. Translation, Parody, Kitsch. Chicago, IL: University of Chicago Press.

Mayhew, Jonathan. 2018. Lorca's Legacy. Essays in Interpretation. Abingdon: Routledge.

Medina, Pablo and Mark Statman. 2008. Introduction to Poeta en Nueva York. New York: Grove Press, xv-xxii.

Merwin, William Stanley. 2005. Introduction to The Selected Poems of Federico García Lorca. New York: New Directions, xi-xvi.

Morla Lynch, Carlos. 2008. En España con Federico García Lorca. Páginas de un diario íntimo. Sevilla: Renacimiento.

Muñoz Molina, Antonio. 2010. 'El poeta perdido y encontrado en Nueva York' [The Poet Lost and Found in New York]. Introduction to The Poeta en Nueva York. Granada: Diputación de Granada, v-ix..

Nordlund, David E.C. 1998. 'Cementerio judío: Lorca's Cryptic Dream of the Wandering Jew', Revista Hispánica Moderna, 51(1), 46-63.

Ortega López, José. 1986. 'El Gitano y el Negro en la Poesía de Federico García Lorca', Cuadernos Hispanoamericanos, 433-434, 145-168.

Povey, John. 1977. Roy Campbell. New York: Twayne Publishers.

Pozo Felguera, Gabriel. 2009. Lorca. El Último Paseo [Lorca. The Last Walk]. Granada: Ultramarina.

Rampersad, Arnold. 2002. The Life of Langston Hughes, Volume II: 19411967: I Dream a World. Oxford: Oxford University Press.

Río, Ángel del. 1941. Federico García Lorca (1899-1936). Vida y Obra. New York: Hispanic Institute in the United States.

Río, Ángel del. 1952. Vida y Obras de Federico García Lorca. Colección Estudios Literarios, III. Zaragoza: Heraldo de Aragón.

Río, Ángel del. 1955. 'Poeta en Nueva York: Twenty Five Years After'. Introduction to Poet In New York. New York: Grove Press.

Rivas Cherif, Cipriano. 1957. 'Poesía y Drama del Gran Federico: La Muerte y la Pasión de García Lorca I/II/III', Palabra de Lorca, 540-580.

Rogers, Gayle. 2012. Modernism and the New Spain. Britain, Cosmopolitan Europe, and Literary History. Oxford: Oxford University Press.

Sager, Juan Carlos. 1999. 'Comprehension and Interpretation in the Multiple Translations of Federico García Lorca's Poeta en Nueva York', Quaderns. Revista de Traducció, 3, 81-99.

Sahuquillo, Ángel. 2007. Federico García Lorca and the Culture of Male Homosexuality. Jefferson, NCarolina: McFarland and Company.

Scaramella, Evelyn. 2014. 'Translating the Spanish Civil War: Langston Hughes's Transnational Poetics', Massachusetts Review, 55(2), 177-188.

Scaramella, Evelyn. 2017. 'Imagining Andalusia. Race, Translation and the early Critical Reception of Federico García Lorca in the U.S', Revista Canadiense de Estudios Hispánicos, 41(2) Invierno 2017, 417-448.

Schreckenberg, Stefan. 2006. 'La conmemoración del Centenario de García Lorca como contribución a la memoria cultural de España: dos documentales de TVE y Canal+', ed. en Ulrich Winter, 223-237.

Simon, Greg. 1992. 'Sobre dos palabras: 'Norma' y 'Hueco', Boletín Fundación Federico García Lorca, 6, 10-11, 27-29. 
Smith, Paul Julian. 1998. The Theatre of García Lorca. Text, Performance, Psychoanalysis. Cambridge: Cambridge University Press.

Soto, Isabel. 2000. 'Crossing Over: Langston Hughes and Lorca' in Place That Is Not a Place. Essays on Liminality and Text, ed. Isabel Soto. Madrid: The Gateway Press, 115-132.

Spender, Stephen. 1949. The God that Failed. New York: Harper.

Spender, Stephen and Joan Gili. 1943. Foreword to Selected Poems of Federico García Lorca. London: Dolphin Press.

Stainton, Leslie. 1998. Lorca: A Dream of Life. London: Bloomsbury.

Trend, John Brande. 1926. Alfonso the Sage and other Spanish Essays. London: Constable and Company.

Trend, John Brande. 1956. Lorca and the Spanish Poetic Tradition. Oxford: Blackwell.

Umbral, Francisco. 2012. Lorca. Poeta Maldito [Lorca. Poète Maudit]. Barcelona: Planeta.

Valis, Noel. 2014. 'Lorca's agonía republicana and its aftermath', Bulletin of Spanish Studies, 91, 267-294.

Venuti, Lawrence. 1995. The Translator's Invisibility. Abingdon: Routledge.

Venuti, Lawrence. 1998. The Scandals of Translation. Towards an Ethics of Difference. Abingdon: Routledge.

Walsh, Andrew Samuel. 2017. 'Lorca's Poeta en Nueva York as a Paradigm of Poetic Retranslation' in Literary Retranslation in Context, eds. Susanne M. Cadera and Andrew Samuel Walsh. Oxford: Peter Lang, 21-51.

White, Steven. 1992. 'Miseria y esplendor en la traducción de Poeta en Nueva York' [Misery and Splendour in the Translation of Poeta en Nueva York], Boletín de la Fundación Federico García Lorca, 10-11, 37-39.

Williams, William Carlos. 1939. 'Federico García Lorca', The Kenyon Review, $1(2), 148-158$.

Young, Howard. 1992. 'Sombras fluviales: Poeta en Nueva York y The Waste Land' [River Shadows: Poeta en Nueva York and The Waste Land], Boletin de la Fundación Federico García Lorca, 10-11, 165-177.

Young, Howard. 1999. 'La primera recepción de Federico García Lorca en los Estados Unidos (1931-1941)' [The Early Reception of Federico García Lorca in the USA (1931-1941)] in América en un poeta. Los viajes de Federico García Lorca al nuevo mundo y la repercusión de su obra en la literatura americana [America in a Poet. The Journeys of Federico García Lorca to the New World and the Repercussion of His Work in American Literature], ed. Andrew A. Anderson. Sevilla: Universidad Internacional de Andalucía, 105-118. 